\title{
Stratigraphy and tectonic setting of the Barriga Negra Formation in Uruguay: an update
}

\author{
Pablo Núñez Demarco ${ }^{1,2 *}$ (D), Henri Masquelin' (D), Elena Peel' (D, Leda Sánchez Bettucci ${ }^{1,3}$ (D)
}

\begin{abstract}
The aim of this work is to propose a new stratigraphic scheme of the Barriga Negra Formation, in order to solve the controversies in one of the most discussed units of Uruguay. Here, we introduce a new map (unmodified since 1984) and amend the stratigraphic profile for the Barriga Negra Formation, establishing the correct sequence, order and thickness, dividing it in four members (Volcaniclastic, Arkosic Conglomerate, Calcareous Conglomerate and Petromictic Conglomerate Member). We describe by first time the presence of basal volcanic and volcanoclastic rocks that implies a tectonic active environment. Volcaniclastic rock dating yield an U-Pb concordia age of $633 \pm 3.4$ Ma. Moreover, we show that this unit has no stratigraphic continuity with other units that previously were used to constrain its stratigraphic position, age and paleoenvironment. We confirm unequivocally that the unit is as a continental conglomeratic sequence deposited in arid and active tectonic conditions, and not transitional passive margin deposits as some works claim. Finally, we revisit the metamorphism, deformation, stratigraphy, structural relationships of this unit and identify new basement units. As consequence of this new evidence, we reexamine its correlation with other regional units. This work is also a key to understand the chaotic stratigraphic proposals of Uruguay..
\end{abstract}

KEYWORDS: Barriga Negra Formation; Paleoenvironment; Sedimentation-tectonics; Neoproterozoic; South America.

\section{INTRODUCTION}

Several low-grade metamorphic volcano-sedimentary and sedimentary (conglomerate) units have been described overlying the igneous and metamorphic basement of Uruguay and Rio Grande do Sul (Midot 1984, Fragoso-Cesar et al. 1987, Basei et al. 2000). However, due to a tectonically complex history and the lack of appropriate geological maps, the Uruguayan units are subject to constant stratigraphic controversy. The Barriga Negra Formation is one of these controversial units; it is a thick succession of reddish conglomerates, arkoses and pelites, which is assumed to be Neoproterozoic in age (e.g., Midot 1984, Fambrini et al. 2005a). It has been described as it rests unconformably over its basement (Walther 1919, Midot 1984, Fambrini et al. 2005a, Masquelin et al. 2017), as concordant (Preciozzi \& Fay 1988, Gaucher 2000) or even interbedded with it (Caorsi \& Goñi 1958). Its bedding was described with regular dip around $10^{\circ}-20^{\circ}$ E (Midot 1984, Preciozzi \&

\footnotetext{
${ }^{1}$ Departamento de Geodinámica Interna, Instituto de Ciencias Geológicas, Facultad de Ciencias, Universidad de la República Montevideo, Uruguay.

E-mails: pnunez@fcien.edu.uy, emasquelin@fcien.edu.uy, elena@fcien.edu.uy, leda@fcien.edu.uy

${ }^{2}$ InGeBa, Facultad de Ciencias Exactas y Naturales, Universidad de Buenos Aires - Buenos Aires, Argentina.

${ }^{3}$ Dirección Nacional de Minería y Geología - Montevideo, Uruguay.

${ }^{*}$ Corresponding author.
}

(c) 2019 The autors. This is an open access article distributed under the terms of the Creative Commons license.
Fay 1988, Bossi \& Navarro 1991) and $40^{\circ}-45^{\circ} \mathrm{E}$ (McMillan 1933, Fragoso-Cesar et al. 1987). These rocks were even associated and mapped together indistinctly with sedimentary and metamorphic units (Preciozzi et al. 1979, 1985, Gaucher 2000). Its tectonic interpretation is also controversial. It was interpreted as molasse deposits (Bossi et al. 1975, Preciozzi et al. 1979, Fragoso-Cesar et al. 1987), as intracontinental rift deposits (Fambrini et al. 2005a), and as passive margin transitional marine-coastal environment (Gaucher 2000, Gaucher et al.2003). Moreover, the Barriga Negra sedimentary sequence was defined by Midot (1984) and redefined by many others, changing several times their stratigraphic position (Preciozzi et al. 1985, Fragoso-Cesar et al. 1987, Preciozzi \& Fay 1988, Bossi \& Navarro 1991, Gaucher 2000, Sánchez Bettucci et al. 2010b). Furthermore, Barriga Negra Formation is a key part of several stratigraphic proposals and controversies in the Uruguayan Neoproterozoic successions, especially regarding to the interpretation of the Dom Feliciano Belt, and tectonic subdivisions of Uruguay. For example, some authors consider Barriga Negra Formation as a post-orogenic sequence part of the Dom Feliciano Belt, overlaying a meta-volcano-sedimentary sequence (a schist belt) and granitic intrusions formed in an orogenic environment (Basei et al. 2000, Sánchez Bettucci et al. 2010b, Masquelin et al. 2017, and references therein). Others authors (Gaucher 2000, Gaucher et al. 2003, Bossi \& Gaucher 2004, 2014, Blanco et al. 2009) do not accept the existence of the Dom Feliciano Belt in the area, and interpret the opposite scenario; they consider Barriga Negra Formation as the middle or bottom of a marine-coastal sequence, that overlies 
sedimentary units (not metamorphic as the previous model) and the surrounding granitic intrusions as anorogenic, related to a passive margin in an extensional tectonic environment.

The aim of this work is to present the results of a new detailed structural, stratigraphic and petrographic study of the Barriga Negra Formation, with the focus on:

- to present a new stratigraphic, petrographic and geochronological study for the unit expanding and reordering the original ones;

- to check the stratigraphic continuity with other units that previously were used to constrain its stratigraphic position, age and paleoenvironment;

- to describe the different lithofacies and members;

- to discuss its stratigraphic relationships, diagenesis, metamorphism, deformation, and age;

- to discuss the tectonic setting and the regional meaning of the new proposal.

\section{GEOLOGICAL FRAMEWORK}

The Archean to Proterozoic basement outcrops mainly in the southern portion of Uruguay. At the north, it is restricted to the so-called "crystalline islands" (CuñapirúVichadero in Rivera and Aceguá in Cerro Largo Department). This basement represents $44 \%$ of the outcrops in Uruguay (Fig. 1). It consists of metamorphic and plutonic intrusive rocks, as well as various hypabyssal dyke swarms. The metamorphic rocks comprise gneisses, schists and amphibolites and gradual transitions between gneisses, migmatites and granitic rocks. These units were affected by several events involving folding, intrusions, anatexis, erosion, and intense weathering. These units are distributed within several tectonic blocks and terranes as shown in Figure 1. Besides, in its full extent, interbedded metamorphic belts are observed (Fig. 1). These belts comprise rocks with volcanic and sedimentary protolith, and its metamorphism and/or deformation vary between medium and very low degree, and are commonly affected by igneous intrusions.

The basement units are covered by Phanerozoic sedimentary deposits. Most of the southern Phanerozoic deposits in Uruguay are linked to the main extensional event during the Atlantic Ocean formation. This event was responsible for a strong fracturation and volcanic activity, that generated the Mesozoic Santa Lucía and Laguna Merín basins (Fig. 1). Both basins record volcanic flows during the Middle Jurassic and Early Cretaceous times, that are grouped in the Puerto Gómez Formation (Walther 1927, Caorsi \& Goñi 1958, Bossi 1966), Arequita Formation (Bossi 1966) and Valle Chico Formation (Ferrando \& Fernández 1971, Gómez Rifas \& Masquelin 1996, Muzio 2000, Muzio et al. 2009). Associated with this volcanism, a syn-rift, alluvial reddish conglomerates deposits occur, as part of the Migues Formation (Bossi \& Navarro 1991) or as the Cañada Solís Formation (De Santa Ana \& Ucha 1994).

\section{The Dom Feliciano Belt}

This orogenic belt groups lithologies that are understood to be associated with the Brasiliano orogenic event (Fig. 1), limiting to the North-West with the Nico Perez Terrane (Bossi \& Campal 1992, Basei et al. 2000, Sánchez Bettucci et al. 2010b, Oyhantçabal et al. 2010). This structural domain includes a metamorphic schist belt known as Lavalleja Group (Sánchez Bettucci 1998) the Polanco Marbles (Goñi 1958), the Carapé Complex, the Campanero Unit (Sánchez Bettucci et al. 2003, 2010b, Oyhantçabal et al. 2011) and Las Tetas Complex (Hartmann et al. 2001). Several authors have contributed to the knowledge of this belt of igneous and metamorphic rocks, generating different models for its genesis and evolution. All studies consider that this orogenic belt is the result of a complex evolution, comprising a collisional orogenic event followed by a continental transcurrent movement and post-collisional collapse, correlated with African orogenic belts (Hasui et al. 1975, Fragoso-Cesar 1980, Fragoso-Cesar et al. 1987, Fernandes et al. 1992, Chemale Jr. 2000, Sánchez Bettucci 1998, Basei et al. 2000, 2005, 2008, Konopásek et al. 2005, 2008, Oyhantçabal et al. 2010, 2011, Goscombe \& Gray 2008, Gross et al. 2009, Almeida et al. 2010, Sánchez Bettucci et al. 2010b, Masquelin et al. 2011, Saalmann et al. 2011, among others).

\section{Lavalleja Group}

Lavalleja Group, was originally defined as the Minas Series (MacMillan 1933), then Lavalleja Metamorphic Series (Goñi 1958, Goñi \& Hoffstetter 1964), but Bossi \& Navarro (1991) rename it following modern nomenclatures. Sánchez Bettucci (1998) performed an extensive mapping and petrological analyses of the southern portion of de Dom Feliciano Belt amending the Lavalleja Group following the stratigraphic criteria of Midot (1984) and Preciozzi (1989), grouping three formations (i.e., Minas, Fuente del Puma and Zanja del Tigre) with intensely deformed meta-sedimentary and meta-volcanic successions. This unit, considered basement of Barriga Negra Formation, is one of the most recognized units in the region (Sánchez Bettucci \& Ramos 1999, Sánchez Bettucci et al. 2003, 2010b, Pazos et al. 2008, Fambrini et al. 2005a, Masquelin et al. 2017, Oyhantçabal et al. 2010, 2011), and an equivalent of the Porongos and Brusque groups from Southern Brazil (Sánchez Bettucci \& Ramos 1999, Basei et al. 2000, Sánchez Bettucci et al. 2003, 2010b, Pazos et al. 2008, Fambrini et al. 2005a, Masquelin et al. 2017, Oyhantçabal et al. 2010, 2011). Although, some authors had published other alternative stratigraphy proposals (Gaucher 2000, Chiglino et al. 2010, Blanco et al. 2010, Poiré et al. 2005, Pecoits et al. 2016), in which the definition and interpretation of Dom Feliciano belt has been questioned (see Bossi \& Gaucher 2014).

\section{Polanco Marbles}

The Polanco Marbles composed by calcareous and dolomitic marbles was defined by Goñi (1958) and formally published by Goñi \& Hoffstetter (1964) in the Lexique Stratigraphique International (Fig. 2). However, there have been some controversies about its authorship because other authors (e.g., Preciozzi \& Fay 1988) used it as an informal unit (see Sánchez Bettucci et al. 
2010a vs. Blanco et al. 2010). This unit was narrowly mapped by several authors (Midot 1984, Preciozzi \& Fay 1988, Preciozzi et al. 1981, Díaz et al. 1990, Bossi \& Navarro 1991, Gaucher 2000), but no general detailed map of the unit and its limits were ever published (see Fig. 2). This unit constitutes the basement of Barriga Negra Formation and was considered as discordant over the Lavalleja Group (Preciozzi \& Fay 1988, Gaucher 2000), being part of the Lavalleja Group (Midot 1984) and even underlying the Lavalleja Group (Hartmann et al. 2001, Bossi \& Gaucher 2014).

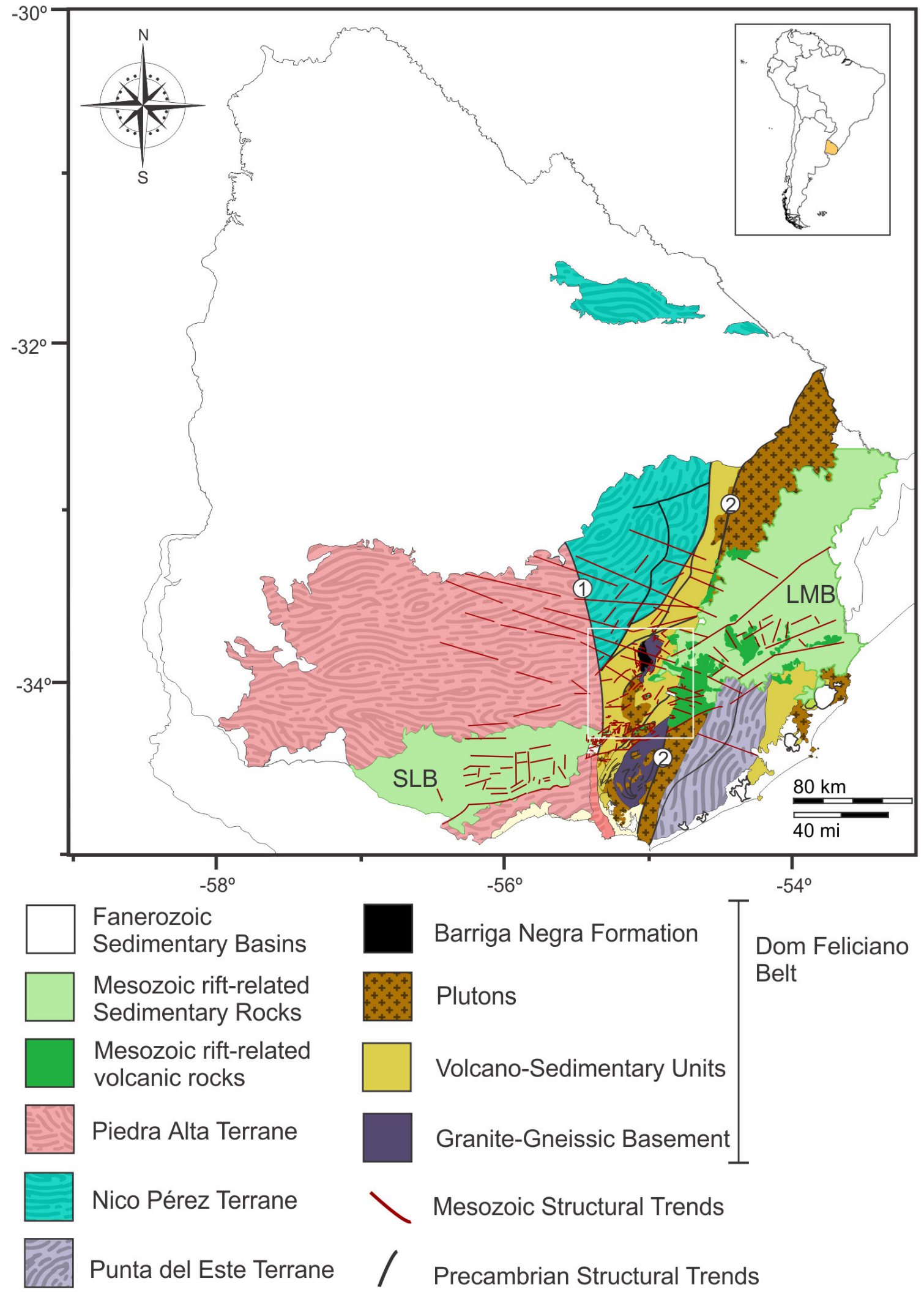

SLB: Santa Lucia Basin; LMB: Laguna Merin Basin; 1: Sarandí del Yí Shear Zone; 2: Sierra Ballena Shear Zone.

Source: modified from Sánchez Bettucci et al. (2010a, 2016), Rossello et al. (1999, 2000), Oyhantçabal et al. (2010), Preciozzi et al. (1979, 1985) and Masquelin et al. (2017).

Figure 1. Main tectonic features of the Uruguayan Precambrian Shield, Neoproterozoic structural trends and Mesozoic basins. The white rectangle indicates the location of Figure 2. 


\section{Arroyo del Soldado Group}

The Arroyo del Soldado Group is represented by pelites, psamites, banded iron formation (BIF's), limestones, and conglomerates sensu Gaucher et al. (1996). These authors suggested that there were units so far incorporated into the Lavalleja Group, without metamorphism (sic) and with different ages. Therefore, they defined this group bringing together these lithologies and separating them from metamorphic successions (sic). One of the considered sedimentary was the Polanco Marbles referred as Polanco Formation (Gaucher et al. 1996, Blanco et al. 2010, Bossi \& Gaucher 2014). However, several authors indicate that low-grade

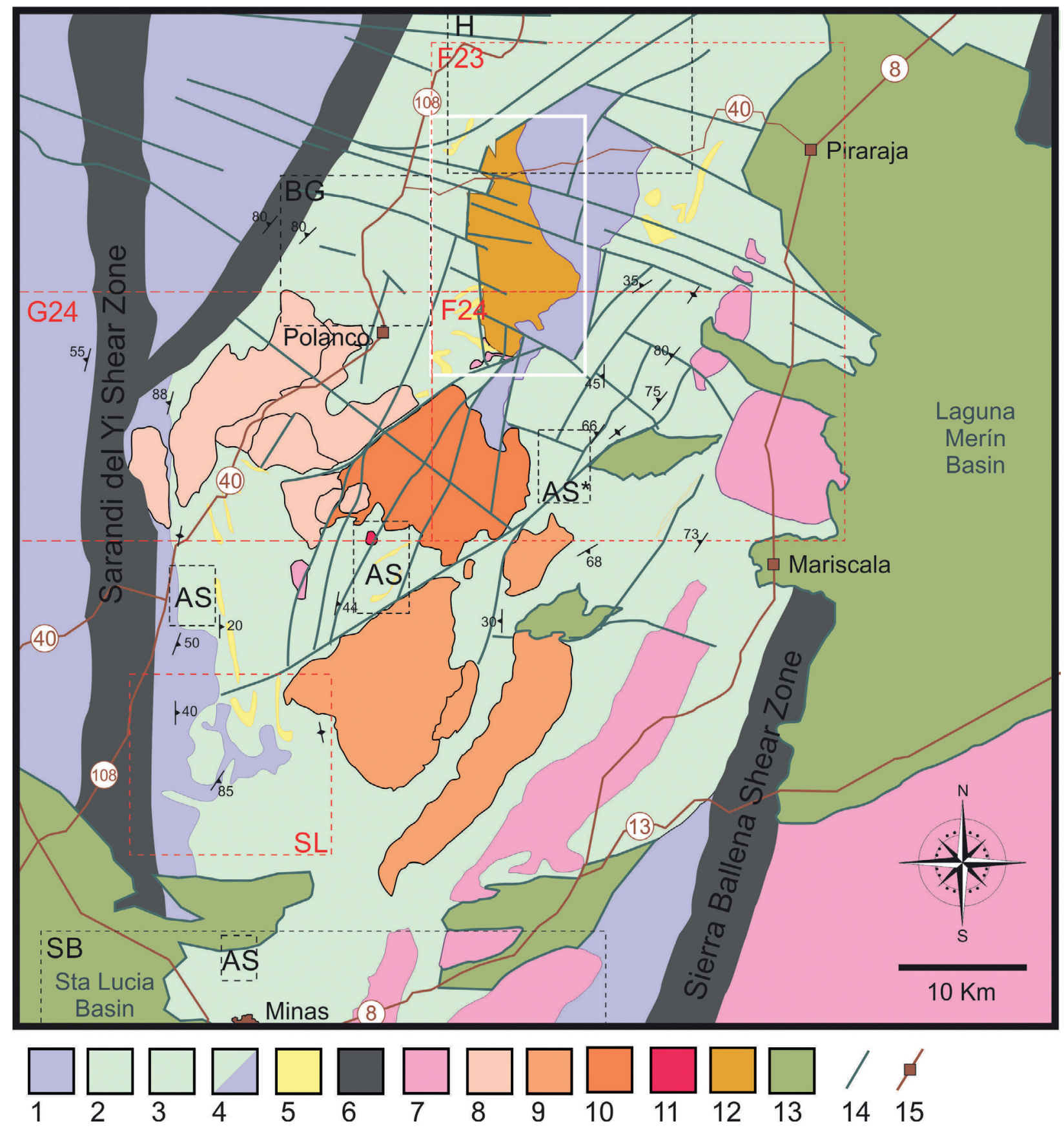

Figure 2. Regional geological and structural map of southern portion of the Dom Feliciano Belt - location in Figure 1. (1) Undifferentiated basement: gneiss, muscovite schists, mylonites, BIFs, and meta-conglomerates and quartzites; (2) Lavalleja Group: marbles, schists and quartzites undifferentiated; (3) Polanco marbles; (4) units identified as Las Tetas Complex by Hartmann et al. (2001); (5) quartzites and meta-sandstones; (6) shear zones; (7) undifferentiated granitoids; (8) Polanco Granitic Complex; (9) and (10) Santa Lucia Batholith; (10) Barriga Negra Granite sensu Preciozzi et al. (1981) or Mangacha Granite sensu Díaz et al. (1990); (11) Mangacha Granite sensu Gaucher (2000) and Bossi \& Gaucher (2014); (12) Barriga Negra Formation; (13) Mesozoic basins; (14) main faults systems; (15) roads and cities. Published maps in the area: (F23) Preciozzi \& Fay (1988); (F24) Díaz et al. (1990); (G24) Preciozzi et al. (1981); (SL) Sanchez Bettucci \& Loureiro (1999); (SB) Sánchez Bettucci (1998); (AS) all the existing maps of the Arroyo del Soldado Group in the area sensu Gaucher (2000), Gaucher et al. (2008) and Bossi \& Gaucher (2014). AS* Type Area where was defined the Stratotype of Polanco Formation sensu Gaucher (2000); (BG) map area of the Manguera Azul Formation proposed by Bossi \& Gaucher (2014). The white rectangle indicates the location of Figure 4. Published maps by the "Uruguayan geological survey" (DINAMIGE) are signalized in dashed red. This map was elaborated in basis of the previous maps of Midot (1984), Preciozzi \& Fay (1988), Preciozzi et al. (1981), Diaz et al. (1990), satellite images and the new detailed magnetic and radiometric survey of Uruguay (Sánchez Bettucci et al. 2016). 
metamorphism affects the Arroyo del Soldado Group (Goñi \& Hoffstetter 1964, Midot 1984, Preciozzi \& Fay 1988, Hartmann et al. 2001, Sanchez Bettucci et al. 2010b, Bossi \& Gaucher 2014). In addition, different authors defined differently this group (see Gaucher 2000, Sánchez Bettucci et al. 2010b). Recently Bossi \& Gaucher (2014) excluded, from the Arroyo del Soldado Group, its main calcareous unit (in the Polanco Marbles type area sensu Goñi \& Hoffstetter 1964, see Fig. 2) and amended it as a new unit (Manguera Azul Formation) based on isotopic differences with other carbonatic successions (in the Polanco Formation type area sensu Gaucher 2000, see Fig. 2). Although, this new interpretation contravenes stratigraphic code - by using chemical criteria for separate units - ; it matches exactly as the original Polanco Marbles definition, but with a new name.

\section{Stratigraphic controversies}

Bossi et al. (2002) and Bossi \& Gaucher (2004, 2014) proposed a whole new stratigraphy for the Uruguayan basement, redefining, regrouping and discarding previously coined units like as Lavalleja Group (Sánchez Bettucci 1998), Carapé granitic complex and Campanero unit (Sánchez Bettucci 1998, Sánchez Bettucci et al. 2003). They also proposed different limits for the Nico Perez Terrane, including units pertaining to the Dom Feliciano Belt. Bossi \& Gaucher (2014) argue that the ages of Lavalleja Group no longer correspond to the Brasiliano orogenic event, but with the Grenvillian cycle and therefore they should be removed and re-defined (see Bossi et al. 2002 vs. Sánchez Bettucci \& Ramos 2002). These authors consider all the calcalkaline Neoproterozoic granitic bodies at the west of Sierra Ballena Shear Zone (Fig. 1) as rift-related magmatism, and the Arroyo del Soldado Group as marine deposits related to a passive margin (Gaucher 2000, Gaucher et al. 2003, Bossi \& Gaucher 2004, 2014, Blanco et al. 2009).

On other hand, Hartmann et al. (2001) defined Las Tetas Complex, putting together meta-conglomerates, quartzites, marbles, calc-silicate rocks and basement gneisses, at the north of Minas city. However, these units were previously mapped as independent units by different authors (e.g., Midot 1984, Preciozzi \& Fay 1988, Sanchez Bettucci 1998) and identified as Lavalleja Group, Polanco Marbles and a "basal gneissic complex" (see Fig. 2).

All those new units and their interpretations (like other proposals by Aubet et al.2014, and Pecoits et al.2016) should be considered alternative proposals as there are not accepted by main part of the national and regional scientific community (see: Sánchez Bettucci \& Ramos 2002, Basei et al. 2000, Pazos et al. 2008, Rapalini \& Bettucci 2008, Sánchez Bettucci et al.2010b, Oyhantçabal et al. 2010, 2011, Almeida et al.2010, Fambrini et al. 2005a, Núñez Demarco 2014, Oriolo et al.2016, Masquelin et al. 2011,2017, among others).

The main reason why there are so many stratigraphic alternatives and redefinitions is mainly due the lack of appropriate mapping. Stratigraphic units and profiles, and geochemical data are continuously being created in very restricted areas, without any appropriate geological context. The units are mapped in regional scale $(1: 500,000)$ or detailed mapped in narrow and unconnected areas without correct definition of their extension, limits nor contacts (see Figs. 2 and 3). As example, the Lavalleja Group is only accurately mapped in its southern half (Preciozzi et al. 1981, Midot 1984, Cosarinsky 1997, Sánchez Bettucci 1998, Sánchez Bettucci \& Ramos 1999, Mallmann et al. 2007), and all show the geological complexity of the region, but there are only inaccurate sketches of their northern portion that vary among different authors (see Gaucher et al. 2003, Rapalini \& Bettucci 2008, Sánchez Bettucci et al. 2003, 2010b, Oriolo et al. 2016, Masquelin et al. 2011, 2017, Pecoits et al. 2016). Yet, despite the fact that there are published dozens of stratigraphic profiles and chemical analyses, there are no detailed maps showing the complete extension of the Arroyo del Soldado Group nor its constituent formations: there are only narrow maps in key-areas (see Fig. 2, and Gaucher 2000, Gaucher et al. 2008, Pecoits et al. 2016, Bossi \& Gaucher 2014) and only regional maps of the Group (Fig. 3), but their extension remarkably differs among publications (see Gaucher 2000, Gaucher et al. 2003, 2008, Hartmann et al. 2001, Mallmann et al. 2007, Rapalini \& Bettucci 2008, Sánchez Bettucci et al. 2003, 2010b, Chiglino et al. 2010, Blanco et al. 2009, 2010, Oyhantçabal et al.2010, Oriolo et al. 2016, Pecoits et al.2016, Masquelin et al. 2017). This lack of concordance in geological records and their structural limits - beyond nomenclature and interpretation differences - proves that there is no real and basic geological knowledge about that units.

Barriga Negra Formation is linked to the aforementioned units, its controversies, redefinitions and interpretations in the Neoproterozoic of Uruguay (Figs. 2 and 3). It belongs to the Dom Feliciano Belt overlaying the northern portion of Lavalleja Group (Preciozzi et al. 1993, Sánchez Bettucci 1998, Sánchez Bettucci \& Ramos 1999, Fambrini et al. 2005a, Sánchez Bettucci et al. 2010b), the Polanco Marbles (Midot 1984) and its granite-gneissic basement. Conversely, Gaucher (2000) and Bossi \& Gaucher (2014) included it in the Arroyo del Soldado Group in purportedly stratigraphic continuity with other sedimentary units of the group. In first instance, it was considered overlying the Polanco Marbles (Gaucher 2000), and more recently considered the base of the group, subjacent to the Polanco Formation (Bossi \& Gaucher 2014). Also, it is affected - as well as their related units - by the Mesozoic faulting and magmatism, which distort the already complicated regional stratigraphy (see Figs. 1 and 2). Thus, the right knowledge of the Barriga Negra Formation lithology, limits, internal structure, stratigraphy, and tectonics is fundamental for the support and interpretation of the different stratigraphic proposals of the area.

\section{THE BARRIGA NEGRA FORMATION}

The first descriptions of different rocks units around the region of Barriga Negra stream were due to Sellow (apud Weiss 1830), Walther (1919, 1927), MacMillan (1933) and Caorsi \& Goñi (1958). They described the geology along the channels of the Barriga Negra and Polanco streams, producing the first geological sketches around the lands of President Francisco 
Vidal. Since Bossi (1966) to Preciozzi et al. (1979), the clastic deposits in this region were considered as a member of the Piedras de Afilar Formation (Walther 1927, Jones 1956). Midot (1984), based on the unpublished geological data of
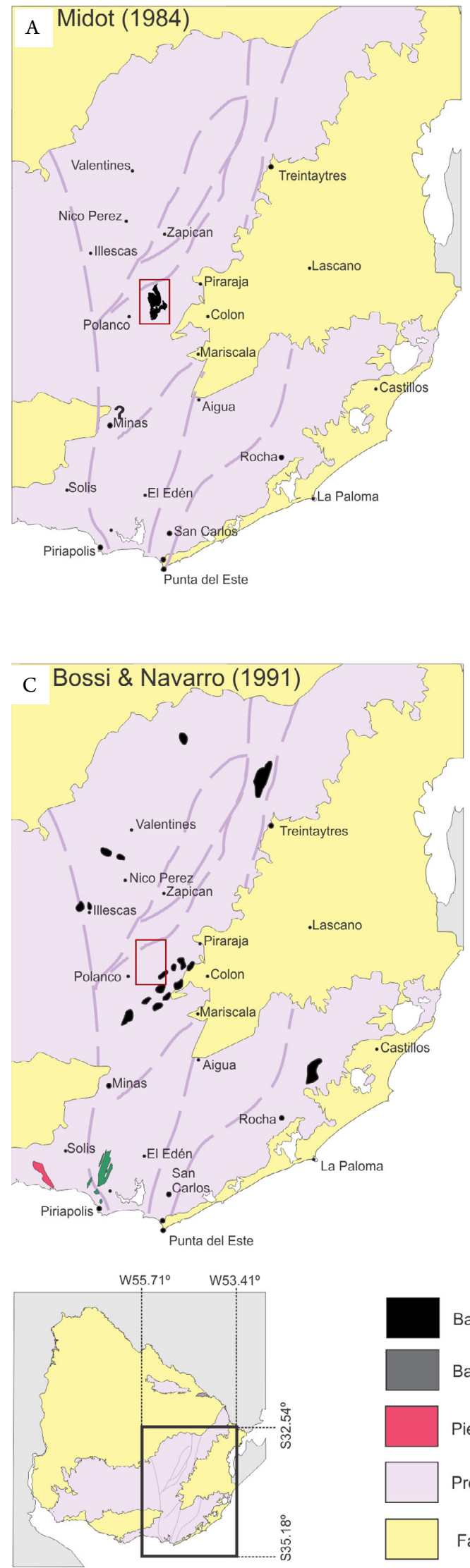

Barriga Negra Formation
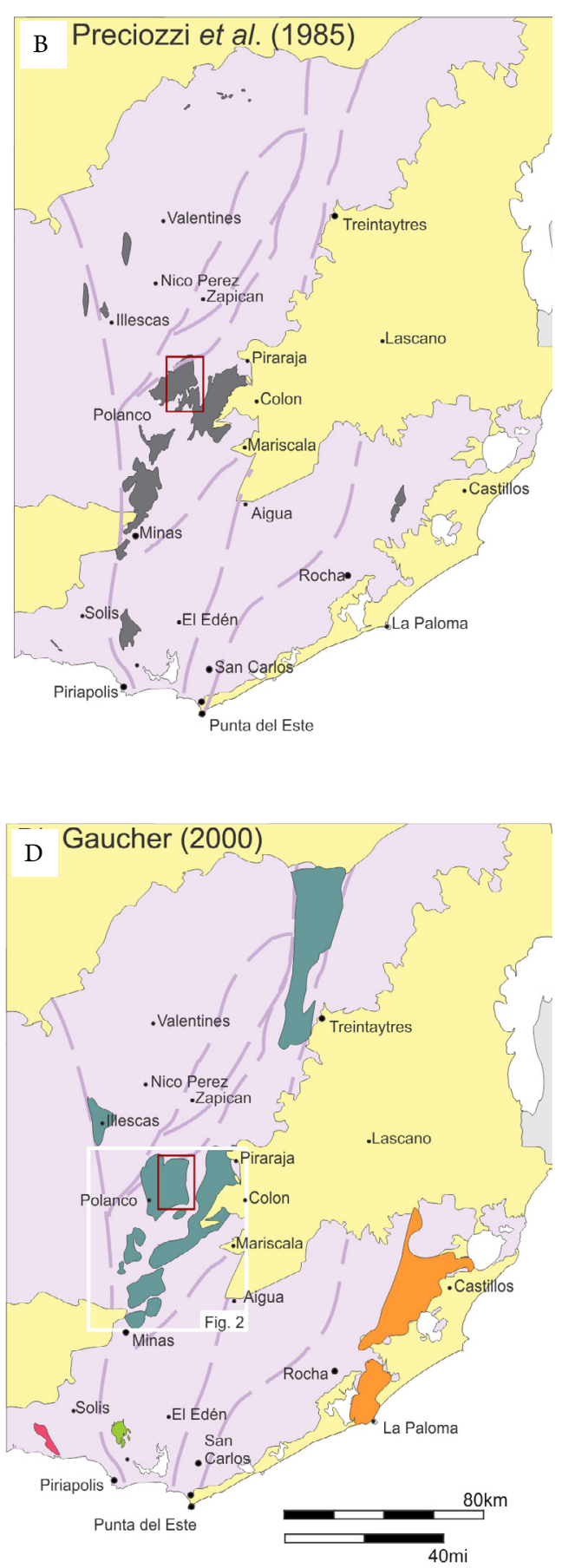

Fay \& Arrighetti (1981), formally defined the Barriga Negra Formation (see Fig. 3A); separating the clastic rocks located near the Barriga Negra stream from the Piedras de Afilar Formation based on lithology, maturity and selection (Midot

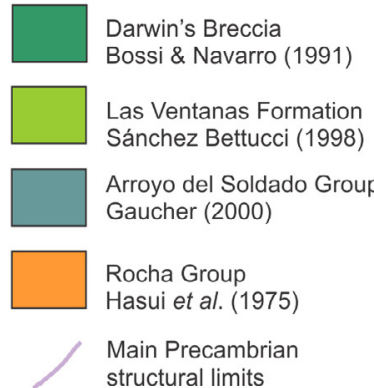

Figure 3. Geological map evolution of the Barriga Negra Unit and correlated units according to Midot (1984), Preciozzi et al. (1985), Bossi y Navarro (1991), Sánchez Bettucci (1998), and Gaucher (2000). Red rectangle indicates the studied area, shown in Figure 4. 
1984). Nevertheless, Preciozzi et al. (1985) formally published it in the Uruguayan Geological Map, the Barriga Negra Group (see Fig. 3B) linking together lithologies that putatively comprise a discordant sedimentary sequence. This group associated several conglomeratic units in the region - that are not spatially related — : sandstones, arkoses, interbedded conglomerates and even quartzites and the underlying calc-pelitic and marble rocks (Polanco Marbles, Goñi 1958, Goñi \& Hoffstetter 1964). Otherwise, Fragoso-Cesar et al. (1987) reviewed the geology of the region and defined the Barriga Negra Formation assembling immature clastic sequences of the Barriga Negra Group, separating them from the surrounding metamorphic rocks (probably without knowing Midot's work, see Fambrini et al. 2005a).

On the other hand, Preciozzi \& Fay (1988) maintained the Barriga Negra Group, and described three units: Paso de los Talas (conglomerates), Arroyo del Soldado (sandstones and quartzites) and Polanco (calcareous rocks), although these authors considered it as informal units (Preciozzi \& Fay 1988). Meanwhile, Díaz et al. (1990) and Bossi \& Navarro (1991) resumed and emended Barriga Negra Formation of Midot (1984) adding to it other conglomeratic units of the region (see. Fig. 3C). Gaucher (2000) includes the Polanco Formation - purportedly without metamorphism - and the Barriga Negra Formation (sensu Midot 1984) in the Arroyo del Soldado Group (see. Fig. 3D), arguing a gradual and concordant transition between them (Gaucher 2000), against the previous authors that reported a lithological unconformity between them (Midot 1984, Fragoso-Cesar et al. 1987). Additionally, Gaucher (2000) presents the first detailed stratotype for this formation, but not a detailed geological map.

Hence, this formation is associated and mapped together with sedimentary and metamorphic units (Preciozzi et al. 1979, 1985, Gaucher 2000, Bossi \& Gaucher 2014), and even its bedding was described inconsistently with regular dip around $10^{\circ}-20^{\circ} \mathrm{E}$ (Midot 1984, Preciozzi \& Fay 1988, Bossi \& Navarro 1991) and $40^{\circ}-45^{\circ} \mathrm{E}$ (McMillan 1933, Fragoso-Cesar et al. 1987). In recent works, Fambrini et al. (2005a) took the definition of Fragoso-Cesar et al. (1987), and they indicate the presence of the discordance between conglomerates and calcareous metamorphic basement (Polanco Marbles). While, Pecoits et al. (2016) considered it discordant with Arroyo del Soldado Group and the Polanco Marbles in basis to "compelling evidence of this unconformity" (Aubet et al. 2014). However, both research groups used in their articles the geological map of Preciozzi et al. (1985), in which the Polanco Marbles are one with the Barriga Negra Formation (Fambrini et al.2005a, Aubet et al. 2014, Pecoits et al. 2016). It proves that the different authors did not know neither the real geologic extent nor the stratigraphy of the studied unit, raising doubt their stratigraphic proposals.

\section{RESULTS}

\section{Redefinition, lithology, facies, and age}

In this work, the Barriga Negra Formation (Midot 1984) is amended. The detailed mapping and petrography (Fig. 4) provide valuable information that allow undertake stratigraphic corrections. The sequence occupies a NS-oriented pull-apart graben, controlled by normal and strike-slip faults. It is also affected by tenuous-open folds with vertical axis in its southernmost and northernmost portions. Moreover, the Barriga Negra Formation is affected by very low-grade and hydrothermal metamorphism - according to the petrographic information and the Kübler index in clay minerals (Cingolani et al. 1990), and cut by some rhyolitic dikes in the southernmost section.

Previous interpretations (Gaucher 2000, Fambrini et al. 2005a) indicate a thickness of ca. $1500 \mathrm{~m}$, but that sequence has variable dips, increasing from $\mathrm{E}$ to $\mathrm{W}$, from less to 10 to $60^{\circ}$ and striking in average $340^{\circ}$ (Fig. 4). This explains previous discrepancies in the dip measurement of the unit. Geometric reconstruction models of tilting suggest a maximum thickness of ca. $3200 \pm 40 \mathrm{~m}$ for the non-eroded sequence (Núñez Demarco 2014).

The exposed sequence of Barriga Negra Formation (using the Hallsworth \& Knox 1999 classification scheme) exhibits four members, from bottom to top:

- a Volcaniclastic Member, about 425 m thick, composed by volcanic and pyroclastic acidic rocks;

- an Arkosic Conglomerate Member, about $912 \mathrm{~m}$ thick, characterized by intraformational arkosic-granule ortho-conglomerates and arkosic-pebble ortho-conglomerates;

- a Calcareous Conglomerate Member, about 200 to $400 \mathrm{~m}$ thick, composed by clast supported oligomictic calcareous-clastic diamictites with sandy matrix;

- Petromictic Conglomerate Member, constituted by grain supported petromictic blocks-grade conglomerates with sandy matrix, with interbedded levels of arkosic sandstones and mudstones, reaching a maximum thickness of 1,650 m (see Fig. 3).

\section{Volcaniclastic Member}

The Volcaniclastic Member is located at the west of the study area, overlying the Polanco Marbles and the Cerro de los Bueyes Quartzites in angular unconformity. Lithologically, it is mainly composed of, about $425 \mathrm{~m}$ thick, acid volcanic and pyroclastic rocks, presenting strong hydrothermal alteration and greenish colorations. Volcanic rocks present vacuoles and phenocrysts reaching $0.5 \mathrm{~mm}$, while the pyroclastic rocks present preserved flow structures, with a mean orientation of $332^{\circ}$ $/ 48^{\circ}$, low angle cross bedding and lithoclasts (see Fig. 5A), which are typical of pyroclastic flows and pyroclastic surge deposits. Volcaniclastic rocks are acidic to intermediate rocks (rhyolites and/or trachytes), according to modal observations. However, specific rock type cannot be determined due the porphyritic texture or strong alteration of the rocks (see Fig. 6). Relict feldspar, plagioclase, hornblende phenocrysts, and opaque minerals are observed. The matrix is composed by fine relictual grains and recrystallized quartz. Secondary crystals of chlorite, actinolite, epidote, sericite and carbonates replacing the feldspar phenocrysts in pseudomorphs are common, suggesting a metasomatic assemblage (Fig. 6).

One sample was collected (BN-286; latitude S33 $51^{\prime} 47.1^{\prime \prime}$, longitude W55 $2^{\prime} 1.8^{\prime \prime} \mathrm{W}$ ) from the pyroclastic rocks on the 
Volcaniclastic Member. About 80 zircons were separated by standard gravimetric and isodynamic techniques. Then, zircons were selected mounted into epoxy resin discs, and scanning electron microscope (SEM) imaging of the zircons under backscatter electron and cathodoluminescence (CL) were obtained to aid in identifying morphological and textural features (cores, overgrowths, and unwanted fractures) using them for the final selection of spot analyses. U-Pb age determinations by laser ablation inductively coupled plasma mass spectrometry (LA-ICP-MS) were carried out at Institute of Geosciences, Universidade de São Paulo (São Paulo, Brazil), according to standard procedures using a Thermo-Fisher Neptune laser-ablation multicollector inductively coupled plasma mass spectrometer equipped with a 193 Photon laser system. All LA-ICP-MS zircon analyses are shown in Table 1. The data are represented in a Tera Wasserburg diagram (Fig. 7C) generated with the program MatLab ${ }^{\circledR}$.

Zircon presents good morphological coherence, in two or three dominant forms. There is a majority of individual subhedral crystals (2/3), whereas few are euhedral and well faceted. They have a homogenous axial relationship, from short to intermediate prisms. One third of the sample is from larger crystals (up to $150 \mu \mathrm{m}$ long) subrounded zircons. On the other hand, the typology is variable. The most euhedral grains present pinacoids (Fig. 7A). According to zircon typology studies (Pupin 1980), these zircons would correspond to crystallized zircons in a magma of intermediate to low temperature $\left(700-600^{\circ} \mathrm{C}\right)$. Zircon population presents a small variance in size. Although there is some roundness, the presence of well-developed faces in different typologies suggests that zircons were generated by fractional crystallization process in a magma chamber and did not suffer major geological processes after this crystallization (e.g., regional metamorphism). However, due to the tectonic conditions to which the volcanic rock was subjected, late processes of hydrothermalism leaching / corrosion of zircons or even crystallization by hydrothermal precipitation should not be ruled out. Cathodoluminescence images of BN-286 sample show most zircons having a regular oscillatory zoning (90\%). These zircons do not show any distinct core-rim division, but they have a CL illumination gap between an internal oscillatory zoned part with dark CL and external oscillatory zoned part with brighter CL (Fig. 7B). The other zircons (10\%) exhibit cores of different nature. There are extremely dark CL-illuminated, homogeneous rounded cores (four grains). Some grains have two cores like them, which suggest an incompletely magmatic digestion process, initiated from larger xenocrysts.

U-Pb (LA-ICP-MS) dating (Fig. 7 and Tab. 1) of 36 spots in 33 zircons, yield an age of $631.9 \pm 3.4 \mathrm{Ma}$. The ${ }^{206} \mathrm{~Pb} /{ }^{238} \mathrm{U}$ ages are between 613 and 662, whereas the mean square weighted deviation (MSWD) of concordance is 0.66 . Six zircon ages with high degree of inheritance were eliminated. Indeed, all the eliminated grains are rounded, and two of
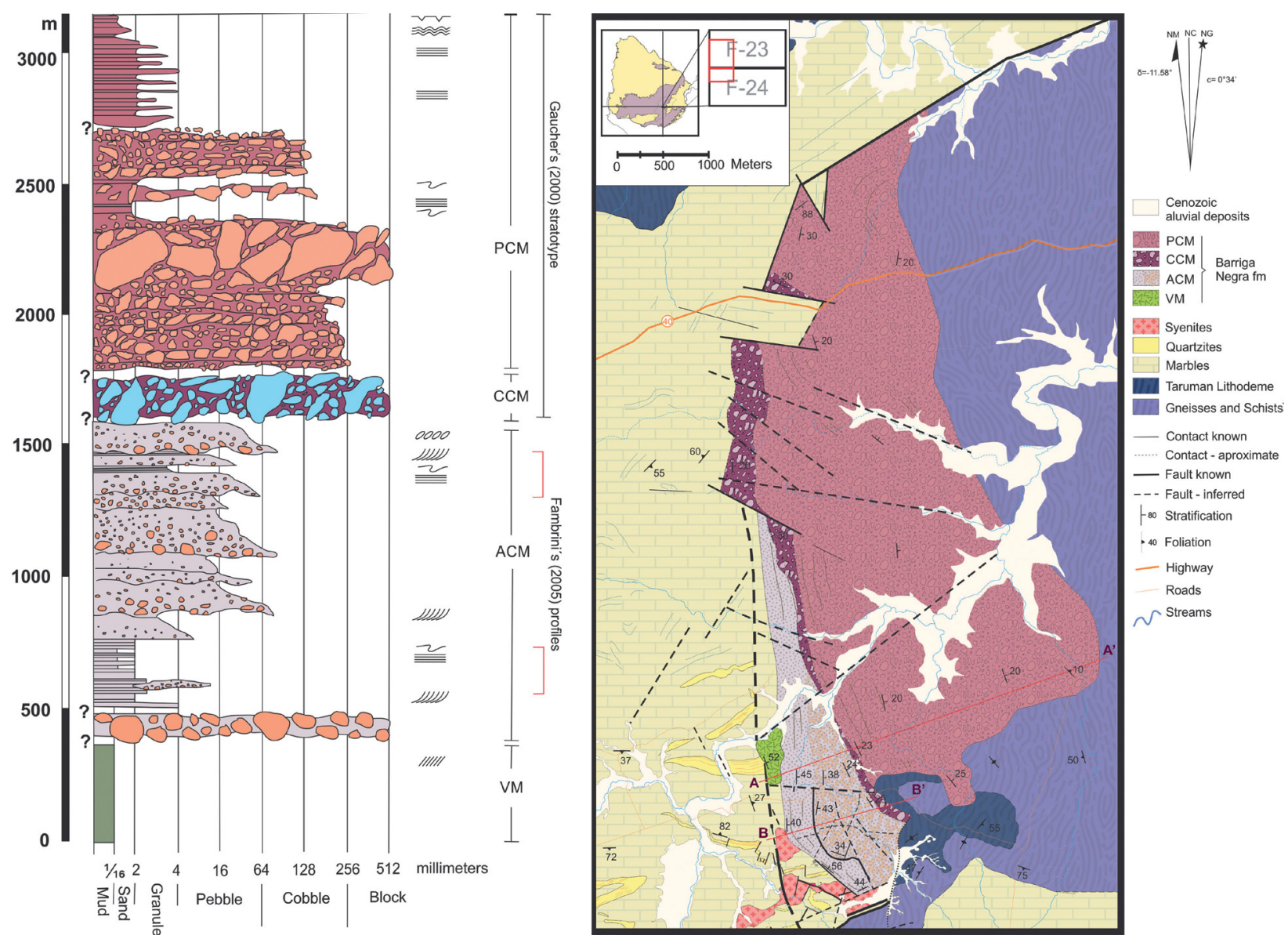

VM: volcaniclastic member; ACM: arkosic conglomerate member; CCM: calcareous conglomerate member; PCM: petromictic conglomerate member.

Figure 4. Stratotype and map of the Barriga Negra Formation. Sections previously described by other authors are indicated in the stratotype (Fambrini et al. 2005a, Gaucher 2000). 
them (10.1 and 27.1) have dark CL-illuminated elliptical cores, whose geochemical content were probably enriched in common $\mathrm{Pb}$, and could be the source of contamination.

\section{Arkosic Conglomerate Member}

The Arkosic Conglomerate Member of Barriga Negra Formation outcrops at the south-west of the study area, along
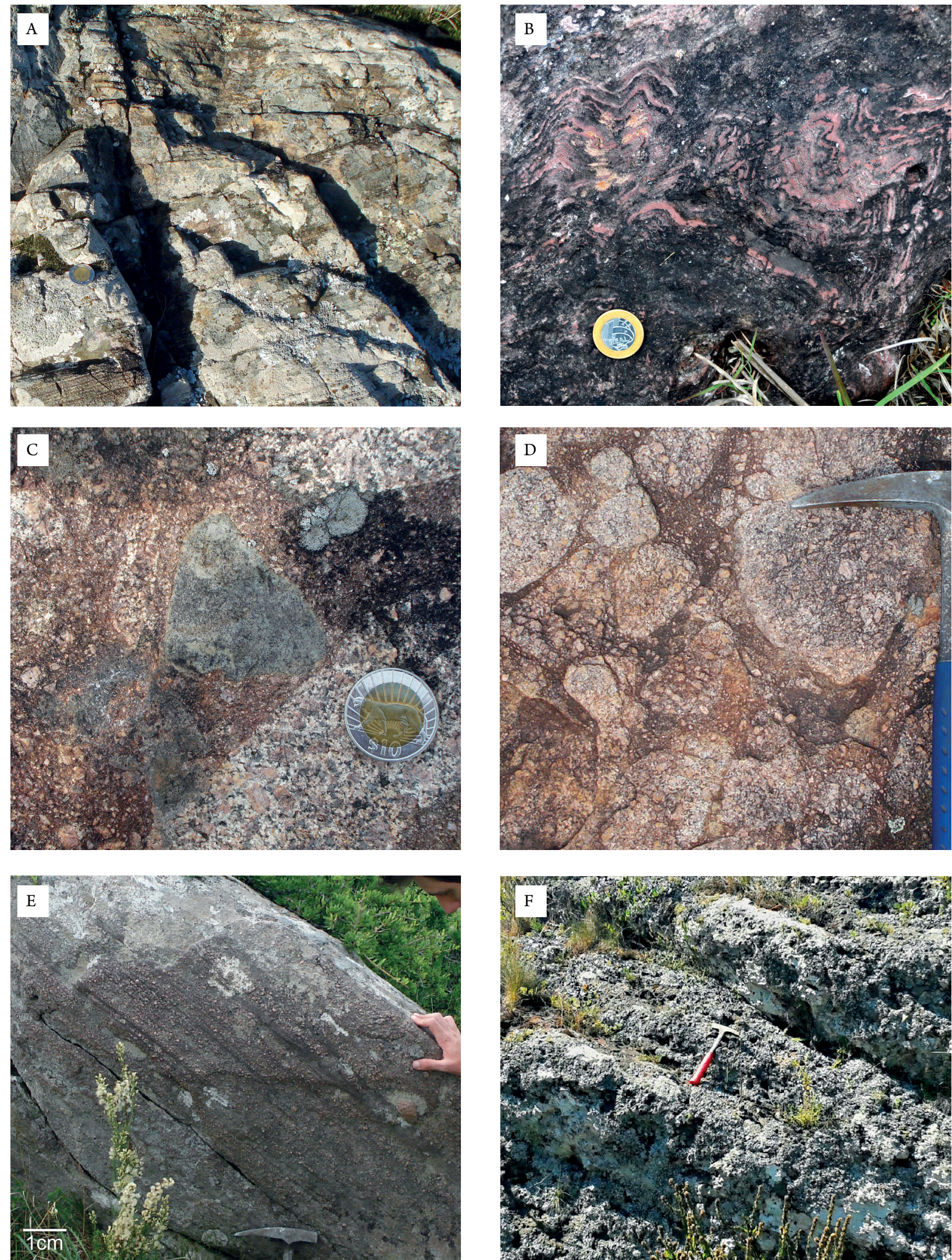

Figure 5. (A) Cross stratification in the pyroclastic levels in the volcaniclastic member; (B) convolute lamination in pelitic levels of the lower arkosic conglomerate member of Barriga Negra Formation; (C) and (D) basal conglomerate with clast of syenite and the volcaniclastic member in contact with the syenite Doña Eustaquia; (E) outcrop of the lower part of the arkosic conglomerate member, parallel, wavy and cross stratification can be observed; (F) outcrop of the upper part of the arkosic conglomerate member, parallel stratification in cobble conglomerates is shown. 

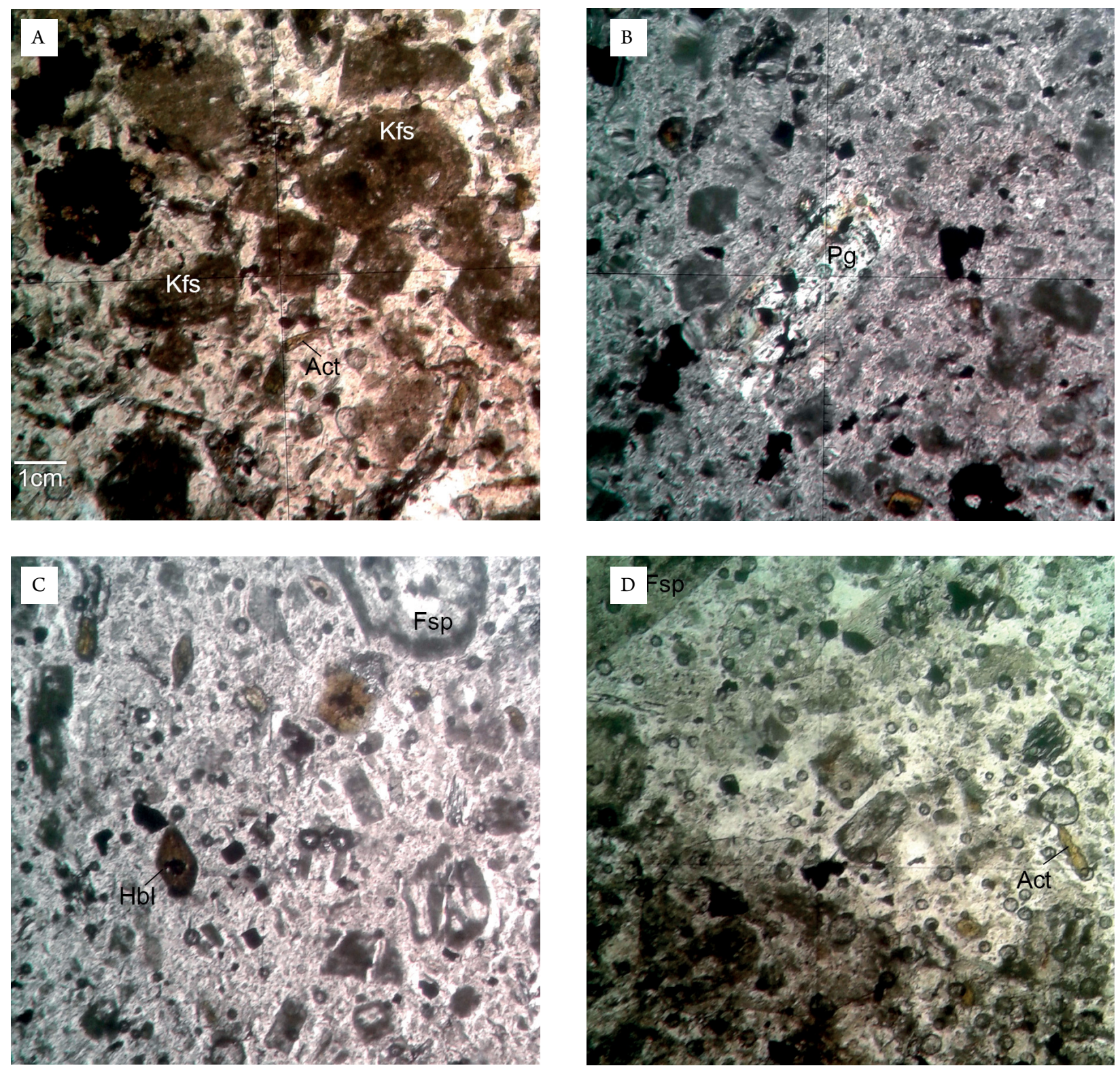

Figure 6. Photomicrographs of the Barriga Negra volcaniclastic member. The rock is composed mainly by feldspar (Fs), plagioclase (Pg), hornblende $(\mathrm{Hbl})$ and opaque minerals, in quartz rich matrix. Chlorite, actinolite, epidote and sericite are common secondary minerals. Minerals are mostly relictual. (A) volcanic matrix; (B) strong saussuritization and corrosion affect the feldspar and plagioclase crystals; (C) volcanic clast in pyroclastic rock; (D) limit between a volcanic clast and the volcanic matrix. All images have the same scale, as shown in Figure 6A.
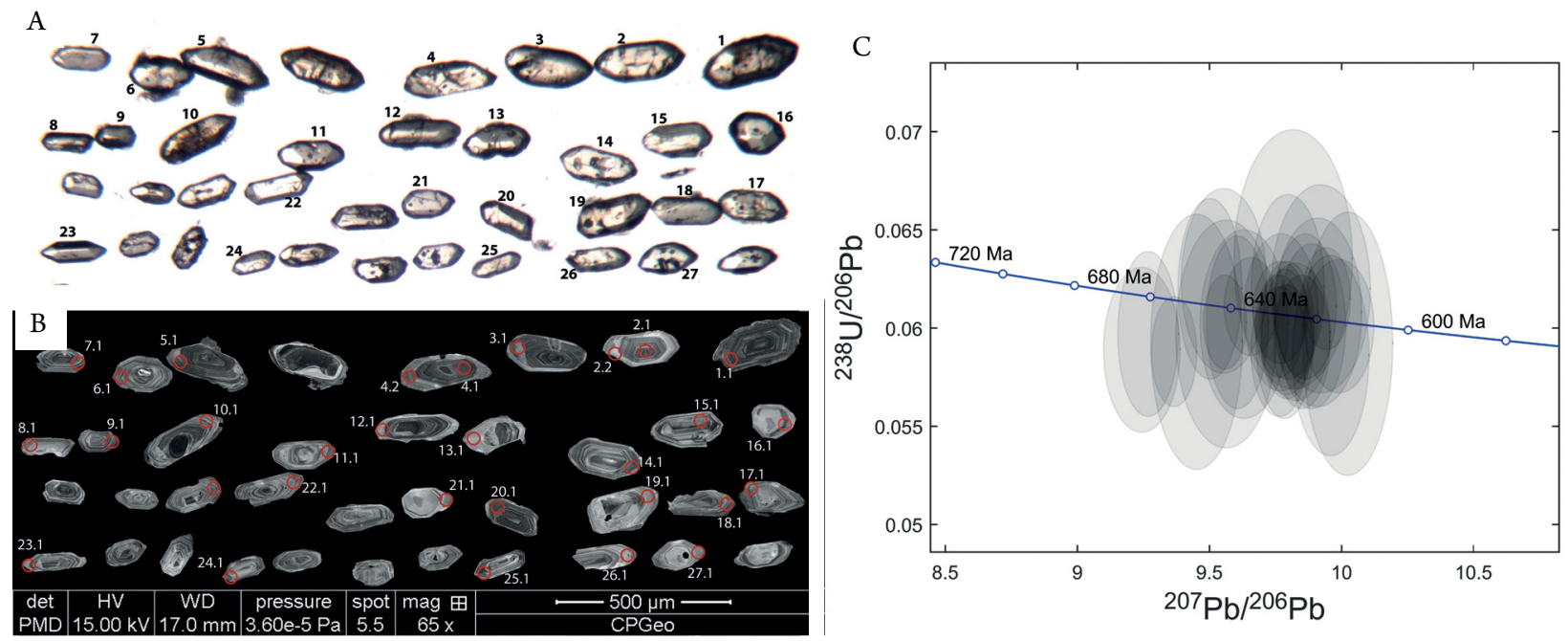

Figure 7. Zircon plate of sample BN-286 showing (A) the morphology of grains by using binocular microscope, and (B) the internal texture of zircon crystals by catholuminescence $(\mathrm{CL})$; red circles are the setting of laser ablation. Tera-Wasserburg diagram (C) for zircons of the sample BN-286 showing an age of $631.9 \pm 3.4 \mathrm{Ma}$. 
Table 1. Laser ablation inductively coupled plasma mass spectrometry (LA-ICP-MS) U-Th-Pb data on zircons of the volcaniclastic member sample BN-286 (latitude S3351'47.1”, longitude W55²'1.8”) of the Barriga Negra Formation. SPL 2,491, Excimer Laser - 193 nm, 6 Hz, $7 \mathrm{~mJ}, 32 \mathrm{~mm}$, ablation time - $40 \mathrm{~s}$. All isotopic ratios are radiogenic lead.

\begin{tabular}{|c|c|c|c|c|c|c|c|c|c|c|c|c|}
\hline \multirow{4}{*}{ Spot } & \multirow{2}{*}{$\begin{array}{c}\text { Total } \backslash \\
\text { common }\end{array}$} & \multicolumn{11}{|c|}{ Ratios } \\
\hline & & $\mathbf{P b}$ & Th & $\mathbf{U}$ & \multirow{3}{*}{$\mathbf{T h} / \mathbf{U}$} & \multirow{3}{*}{${ }^{207} \mathrm{~Pb} /{ }^{235} \mathrm{U}$} & \multirow{3}{*}{$1 \sigma$} & \multirow{3}{*}{${ }^{206} \mathrm{~Pb} /{ }^{238} \mathrm{U}$} & \multirow{3}{*}{$1 \sigma$} & \multirow{3}{*}{$\begin{array}{l}\text { corr. } \\
\text { coef. }\end{array}$} & \multirow{3}{*}{${ }^{238} \mathrm{U} /{ }^{206} \mathrm{~Pb}$} & \multirow{3}{*}{$1 \sigma$} \\
\hline & $\mathbf{P b}$ & \multirow{2}{*}{ (ppm) } & \multirow{2}{*}{ (ppm) } & \multirow{2}{*}{ (ppm) } & & & & & & & & \\
\hline & $\%$ & & & & & & & & & & & \\
\hline 33,1 & 2,01 & 8,8 & 26,8 & 66,3 & 0,404 & 0,8139 & 0,0834 & 0,0998 & 0,0017 & 0,68 & 10,0232 & 0,1703 \\
\hline 12,1 & 1,95 & 23,3 & 162,7 & 171,8 & 0,947 & 0,8296 & 0,0427 & 0,1001 & 0,0013 & 0,16 & 9,9904 & 0,1316 \\
\hline 30,2 & 0,62 & 13,1 & 52,1 & 92,8 & 0,561 & 0,8113 & 0,0686 & 0,1004 & 0,0015 & 0,04 & 9,9584 & 0,1449 \\
\hline 4,2 & 0,48 & 29,6 & 63,8 & 216,2 & 0,295 & 0,8531 & 0,0344 & 0,1006 & 0,0009 & 0,46 & 9,9426 & 0,091 \\
\hline 21,1 & 1 & 15,7 & 115,6 & 107,8 & 1,072 & 0,8615 & 0,0631 & 0,1008 & 0,0019 & 0,3 & 9,921 & 0,1878 \\
\hline 16,1 & 1,53 & 20 & 62,6 & 142,6 & 0,439 & 0,8455 & 0,0585 & 0,1009 & 0,0017 & 0,19 & 9,9094 & 0,167 \\
\hline 2,1 & 0,82 & 13,8 & 75,6 & 103,1 & 0,733 & 0,838 & 0,0547 & 0,1011 & 0,0013 & 0,25 & 9,887 & 0,1285 \\
\hline 7,1 & 0,4 & 22 & 56,8 & 145,9 & 0,389 & 0,8538 & 0,048 & 0,1014 & 0,0012 & 0,25 & 9,8633 & 0,1162 \\
\hline 9,1 & 2,08 & 28,1 & 148,5 & 168,7 & 0,88 & 0,8295 & 0,0435 & 0,1015 & 0,0011 & 0,8 & 9,8496 & 0,1069 \\
\hline 14,1 & 0,5 & 28,8 & 170,5 & 186,8 & 0,912 & 0,8385 & 0,0437 & 0,1018 & 0,0014 & 0,01 & 9,827 & 0,1304 \\
\hline 13,1 & 0,3 & 12,8 & 14,1 & 90,6 & 0,156 & 0,8926 & 0,0807 & 0,1019 & 0,0023 & 0,28 & 9,8167 & 0,224 \\
\hline 6,1 & 0,7 & 16,6 & 27,2 & 108,6 & 0,251 & 0,8743 & 0,0605 & 0,1021 & 0,0014 & 0,42 & 9,7966 & 0,1382 \\
\hline 4,1 & 0,54 & 27,5 & 41,6 & 201,9 & 0,206 & 0,8342 & 0,0382 & 0,1021 & 0,001 & 0,05 & 9,7927 & 0,0975 \\
\hline 30,1 & 0,59 & 25 & 68,2 & 205,6 & 0,331 & 0,8445 & 0,0463 & 0,1021 & 0,0011 & 0,79 & 9,7933 & 0,1037 \\
\hline 28,1 & 1,08 & 20,5 & 56,2 & 138,3 & 0,406 & 0,8345 & 0,0497 & 0,1022 & 0,0011 & 0,35 & 9,7849 & 0,1086 \\
\hline 18,1 & 0,59 & 23,5 & - & 152,1 & - & 0,8574 & 0,0492 & 0,1023 & 0,0015 & 0,01 & 9,7707 & 0,1409 \\
\hline 20,1 & 0,08 & 33,2 & 27 & 245,3 & 0,11 & 0,8581 & 0,0342 & 0,1024 & 0,0011 & 0,86 & 9,7677 & 0,1036 \\
\hline 3,1 & 1,45 & 23,2 & 45,1 & 181,5 & 0,248 & 0,8302 & 0,0442 & 0,1024 & 0,0011 & 0,11 & 9,7643 & 0,1074 \\
\hline 5,1 & 1,34 & 34 & 140,9 & 251,1 & 0,561 & 0,8493 & 0,0345 & 0,1024 & 0,0009 & 0,11 & 9,7637 & 0,0905 \\
\hline 15,1 & 0,22 & 32,9 & 31,5 & 281,4 & 0,112 & 0,8721 & 0,0336 & 0,1036 & 0,0011 & 0,01 & 9,6555 & 0,1005 \\
\hline 11,1 & 1,6 & 20,8 & 45,4 & 136 & 0,334 & 0,8622 & 0,0599 & 0,1038 & 0,0018 & 0,01 & 9,631 & 0,1666 \\
\hline 31,1 & 3,52 & 16,4 & 59,6 & 112,5 & 0,529 & 0,865 & 0,0581 & 0,1041 & 0,0013 & 0,01 & 9,6061 & 0,1176 \\
\hline 22,1 & 0,37 & 17,6 & 27,2 & 122,7 & 0,222 & 0,8607 & 0,0713 & 0,1046 & 0,0021 & 0,01 & 9,563 & 0,1911 \\
\hline 25,1 & 0,5 & 34,4 & 77,5 & 256 & 0,303 & 0,8703 & 0,0337 & 0,1046 & 0,0009 & 0,27 & 9,5588 & 0,0814 \\
\hline 17,1 & 1,46 & 18,4 & 30 & 121,3 & 0,247 & 0,9002 & 0,0587 & 0,1047 & 0,0018 & 0,54 & 9,5543 & 0,1615 \\
\hline 24,1 & 1,49 & 15 & 37,6 & 96 & 0,392 & 0,8997 & 0,0617 & 0,1052 & 0,0013 & 0,46 & 9,502 & 0,1212 \\
\hline 8,1 & 3,21 & 12,5 & 26,5 & 83,6 & 0,317 & 0,8647 & 0,0852 & 0,1058 & 0,0019 & 0,42 & 9,4511 & 0,1736 \\
\hline 29,1 & 0,6 & 28,5 & 79,4 & 188,6 & 0,421 & 0,8649 & 0,0396 & 0,1068 & 0,001 & 0,22 & 9,3659 & 0,0859 \\
\hline 23,1 & 0,65 & 20,8 & 87,1 & 136,6 & 0,638 & 0,8886 & 0,0597 & 0,1079 & 0,0013 & 0,77 & 9,2674 & 0,1148 \\
\hline 19,1 & 1,42 & 14,9 & 68,8 & 103,8 & 0,663 & 0,8782 & 0,0563 & 0,1082 & 0,0017 & 0,31 & 9,2439 & 0,1448 \\
\hline 32,1 & 1,32 & 57,9 & 139,9 & 358,1 & 0,391 & 0,9167 & 0,0264 & 0,1104 & 0,0007 & 0,66 & 9,0573 & 0,0614 \\
\hline 2,2 & 3,77 & 8,3 & 18,7 & 53,1 & 0,351 & 1,0496 & 0,107 & 0,1286 & 0,0025 & 0,58 & 7,7789 & 0,1506 \\
\hline 27,1 & 15,92 & 17,8 & 103,1 & 115,2 & 0,895 & 0,8172 & 0,0538 & 0,1018 & 0,0012 & 0,4 & 9,8243 & 0,1156 \\
\hline 10,1 & 9,43 & 22,2 & 77,3 & 148,3 & 0,521 & 0,8334 & 0,0541 & 0,1036 & 0,0013 & 0,08 & 9,6505 & 0,1217 \\
\hline 26,1 & 14,67 & 19,7 & 1,3 & 121 & 0,011 & 0,8759 & 0,0662 & 0,1048 & 0,0014 & 0,57 & 9,5432 & 0,1302 \\
\hline 1,1 & 10,37 & 35 & 102,7 & 219,6 & 0,468 & 0,9434 & 0,0349 & 0,1103 & 0,001 & 0,01 & 9,0664 & 0,0788 \\
\hline & & Ratios & & & & & $\mathrm{AG}$ & ES & & & & \\
\hline & & & & & & & & & & & Conc. & Conc. \\
\hline Spot & ${ }^{207} \mathbf{P b} /{ }^{206} \mathbf{P b}$ & $1 \sigma$ & ${ }^{208} \mathbf{P b} /{ }^{206} \mathbf{P b}$ & $1 \sigma$ & $T_{206 / 238}$ & $1 \sigma$ & $T_{207 / 235}$ & $1 \sigma$ & $T_{207 / 206}$ & $1 \sigma$ & ${ }^{206} \mathrm{~Pb} /{ }^{238} \mathrm{U}$ & ${ }^{206} \mathrm{~Pb} /{ }^{238} \mathrm{U}$ \\
\hline & & & & & & & & & & & ${ }^{207} \mathrm{~Pb} /{ }^{235} \mathrm{U}^{2}$ & ${ }^{207} \mathrm{~Pb} /{ }^{206} \mathrm{~Pb}$ \\
\hline 33,1 & 0,0592 & 0,0067 & 0,2926 & 0,0292 & 613 & 10 & 605 & 48 & 573 & 242 & 101 & 106 \\
\hline 12,1 & 0,0601 & 0,0034 & 0,2869 & 0,0368 & 615 & 8 & 613 & 24 & 608 & 125 & 100 & 101 \\
\hline 30,2 & 0,0586 & 0,0051 & 0,3106 & 0,0176 & 617 & 9 & 603 & 38 & 552 & 196 & 102 & 111 \\
\hline 4,2 & 0,0615 & 0,0026 & 0,311 & 0,0092 & 618 & 5 & 626 & 19 & 657 & 92 & 98 & 93 \\
\hline 21,1 & 0,062 & 0,0053 & 0,3771 & 0,0336 & 619 & 11 & 631 & 36 & 674 & 185 & 98 & 91 \\
\hline 16,1 & 0,0608 & 0,0048 & 0,3532 & 0,0143 & 620 & 10 & 622 & 31 & 631 & 160 & 99 & 98 \\
\hline 2,1 & 0,0601 & 0,0042 & 0,1571 & 0,0702 & 621 & 8 & 618 & 29 & 607 & 143 & 100 & 102 \\
\hline 7,1 & 0,0611 & 0,0037 & 0,4212 & 0,0187 & 623 & 7 & 627 & 26 & 642 & 128 & 99 & 96 \\
\hline 9,1 & 0,0593 & 0,0034 & 0,4911 & 0,0259 & 623 & 7 & 613 & 24 & 577 & 117 & 101 & 108 \\
\hline 14,1 & 0,0598 & 0,0035 & 0,4142 & 0,0151 & 625 & 8 & 618 & 24 & 595 & 126 & 101 & 104 \\
\hline 13,1 & 0,0635 & 0,0066 & 0,2861 & 0,0234 & 625 & 14 & 648 & 45 & 727 & 256 & 96 & 86 \\
\hline 6,1 & 0,0621 & 0,0047 & 0,417 & 0,0172 & 627 & 8 & 638 & 34 & 678 & 173 & 98 & 92 \\
\hline 4,1 & 0,0593 & 0,0029 & 0,2516 & 0,0135 & 627 & 6 & 616 & 21 & 576 & 105 & 101 & 108 \\
\hline
\end{tabular}


Braz. J. Geol., 49(1):e20180047

Table 1. Continuation.

\begin{tabular}{|c|c|c|c|c|c|c|c|c|c|c|c|c|}
\hline \multirow{3}{*}{$\begin{array}{l}\text { Ratios } \\
\text { Spot }\end{array}$} & \multirow{3}{*}{${ }^{207} \mathbf{P b} /{ }^{206} \mathbf{P b}$} & \multirow{3}{*}{$1 \sigma$} & \multirow{3}{*}{${ }^{208} \mathbf{P b} /{ }^{206} \mathbf{P b}$} & \multirow{3}{*}{$1 \sigma$} & \multicolumn{3}{|l|}{ AGES } & \multirow{3}{*}{$1 \sigma$} & \multirow{3}{*}{$T_{207 / 206}$} & \multirow{3}{*}{$1 \sigma$} & \multirow{3}{*}{$\begin{array}{l}\text { Conc. } \\
{ }^{206} \mathrm{~Pb} /{ }^{238} \mathrm{U} \\
{ }^{207} \mathrm{~Pb} /{ }^{235} \mathrm{U}\end{array}$} & \multirow[b]{2}{*}{\begin{tabular}{|l} 
Conc. \\
${ }^{206} \mathbf{P b} /{ }^{238} \mathrm{U}$ \\
\end{tabular}} \\
\hline & & & & & $T_{206 / 238}$ & $1 \sigma$ & $T_{207 / 235}$ & & & & & \\
\hline & & & & & & & & & & & & ${ }^{207} \mathrm{~Pb} /{ }^{206} \mathrm{~Pb}$ \\
\hline 30,1 & 0,06 & 0,0034 & 0,0976 & 0,0299 & 627 & 6 & 622 & 25 & 603 & 120 & 100 & 103 \\
\hline 28,1 & 0,0592 & 0,0038 & 0,3849 & 0,0134 & 627 & 7 & 616 & 27 & 575 & 132 & 101 & 109 \\
\hline 18,1 & 0,0608 & 0,004 & 0,4198 & 0,0204 & 628 & 9 & 629 & 27 & 631 & 140 & 99 & 99 \\
\hline 20,1 & 0,0608 & 0,0026 & 0,2914 & 0,0271 & 628 & 6 & 629 & 19 & 632 & 94 & 99 & 99 \\
\hline 3,1 & 0,0588 & 0,0033 & 0,1872 & 0,0158 & 629 & 7 & 614 & 24 & 560 & 120 & 102 & 112 \\
\hline 5,1 & 0,0601 & 0,0026 & 0,2431 & 0,0088 & 629 & 6 & 624 & 19 & 609 & 93 & 100 & 103 \\
\hline 15,1 & 0,0611 & 0,0025 & 0,0799 & 0,0121 & 635 & 6 & 637 & 18 & 642 & 91 & 99 & 99 \\
\hline 11,1 & 0,0602 & 0,0048 & 0,4033 & 0,0234 & 637 & 11 & 631 & 33 & 612 & 164 & 100 & 104 \\
\hline 31,1 & 0,0603 & 0,0044 & 0,3661 & 0,0159 & 638 & 7 & 633 & 31 & 613 & 159 & 100 & 104 \\
\hline 22,1 & 0,0597 & 0,0058 & 0,3311 & 0,0163 & 641 & 12 & 631 & 39 & 593 & 211 & 101 & 108 \\
\hline 25,1 & 0,0603 & 0,0024 & 0,202 & 0,0079 & 641 & 5 & 636 & 19 & 616 & 92 & 100 & 104 \\
\hline 17,1 & 0,0624 & 0,0047 & 0,3541 & 0,0193 & 642 & 10 & 652 & 33 & 687 & 172 & 98 & 93 \\
\hline 24,1 & 0,062 & 0,0046 & 0,4987 & 0,0433 & 645 & 8 & 652 & 33 & 674 & 161 & 98 & 95 \\
\hline 8,1 & 0,0593 & 0,0065 & 0,3216 & 0,0197 & 648 & 11 & 633 & 48 & 577 & 254 & 102 & 112 \\
\hline 29,1 & 0,0588 & 0,0028 & 0,4496 & 0,029 & 654 & 6 & 633 & 21 & 558 & 103 & 103 & 117 \\
\hline 23,1 & 0,0597 & 0,0042 & 0,3239 & 0,0166 & 661 & 8 & 646 & 32 & 594 & 158 & 102 & 111 \\
\hline 19,1 & 0,0589 & 0,0042 & 0,2666 & 0,0153 & 662 & 10 & 640 & 30 & 563 & 153 & 103 & 117 \\
\hline 32,1 & 0,0602 & 0,0018 & 0,3599 & 0,0145 & 675 & 4 & 661 & 14 & 611 & 65 & 102 & 110 \\
\hline 2,2 & 0,0592 & 0,0072 & 0,3485 & 0,0389 & 780 & 14 & 729 & 60 & 575 & 250 & 106 & 135 \\
\hline 27,1 & 0,0582 & 0,0041 & 0,3473 & 0,0145 & 625 & 7 & 607 & 29 & 538 & 148 & 103 & 116 \\
\hline 10,1 & 0,0583 & 0,004 & 0,2757 & 0,0317 & 636 & 8 & 616 & 29 & 542 & 143 & 103 & 117 \\
\hline 26,1 & 0,0606 & 0,0046 & 0,4036 & 0,0277 & 642 & 8 & 639 & 35 & 626 & 163 & 100 & 102 \\
\hline 1,1 & 0,062 & 0,0024 & 0,3178 & 0,0156 & 675 & 6 & 675 & 18 & 675 & 85 & 99 & 99 \\
\hline
\end{tabular}

Corr. coef.: correlation coefficient.

the Talas stream. Bedding presents an attitude of ca. $345^{\circ} / 37^{\circ}$ E. Their southern portion is folded where the directions varies from $246^{\circ} / 55^{\circ}$ to $290^{\circ} / 33^{\circ} \mathrm{NE}$. This member overlays the Doña Eustaquia Syenite (Núñez Demarco 2014) in nonconformity, the Polanco Marbles and the Cerro de los Bueyes Quartzites in either angular conformity or para-conformity, and the Volcaniclastic Member (Figs. 5C and 5D) in conformity or paraconformity. A description with two detailed profiles and provenance analysis in the lower half and upper half of this member can be found in Fambrini et al. (2005a) (see Fig. 4). At the South, the first $100 \mathrm{~m}$ of this member consists of a massive conglomerate, characterized by $95 \%$ of well-rounded syenite blocks, up to $40 \mathrm{~cm}$, and $5 \%$ of quartzites and volcanic clasts, with an arkosic massive matrix of reddish color (Figs. 5C and 5D and Figs. 8I and 8J), in the contact with the Doña Eustaquia Syenite and close to the outcrops of the Volcaniclastic Member. The rest of the unit, about $812 \mathrm{~m}$, is characterized by arkosic-granule-conglomerates and arkosic-pebble-conglomerates, lithic and feldspathic sandstones and mudstones (Figs. $5 \mathrm{E}$ and $5 \mathrm{~F}$ ). Beds are decimetric to centimetric and have crude stratification (Fig. 5F). This member is thickening and coarsening-upward, although each package is fining-upward. It is composed by clast supported rock, with inequigranular texture, angulate sand-size to sub-rounded clasts, composed mainly by feldspar ( 90 to $60 \%$ ), quartz ( 10 to $40 \%$ ), and to a lesser extent by lithic fragments (syenite, leucogranite), plagioclase, micas, titanite, opaque minerals, and lithic fragments of gneises and cherts (see also Fambrini et al.2005a). Metamorphic and chloritized micas, irregular to concave-convex contacts, saussuritization of Ca-plagioclase, undulose extinction in quartz, and serpentinization are common (see Fig. 8). Its matrix is scares of arkosic composition, and commonly substituted by epidote, chlorite, and iron oxides, with a range of colors from yellowish gray (5Y 8/4 grayish yellow, Munsell Color 2009), reddish (dusky red 5R 3/4) to pale green (moderate yellowish green $10 \mathrm{~Gy} 6 / 4$ ). Fractures and hollows are filled with fractured grains and mineralizations of sericite, muscovite, epidote, iron oxides, and/or carbonates. Mineral concentrations of iron oxide, biotite, sphene, apatite and zircon are common within grains. Locally, this member presents calcret-, silcret- and ferricretization, attributed to the increased pedogenetic activity during late Cretaceous-early Eocene that affected large areas of Uruguay (Ford \& Gancio 1988, Bossi et al. 1998, Rapalini \& Bettucci 2008, Tófalo \& Morrás 2009).

The conglomeratic facies are characterized by centimetric to metric tabular packages, presenting a plane parallel stratification, somewhat wavy at the bottom and top (Fig. 5F). It is common the occurrence of decimetric sandstones beds and lenses, with frequent occurrence of cross stratification (grooved or tabular; Fig. 5E). According to Fambrini et al. (2005a), there are hummocky cross- stratification, asymmetric ripple marks and undulose lamination, indicating probably paleocurrents with direction WNW. Some pebbly beds have very rounded clasts with imbrication, being more common toward the top (Fragoso Cesar et al. 1987). Fine to medium sandstone beds are generally plane laminated and, occasionally, massive with symmetric ripple marks.

The lower half of this lithological unit (about 300-m tick) is interpreted to have been deposited in a coast environment, dominated by the sandy bedforms (SB) facies (following 
Miall 2006; Tab. 2) and the presence of sedimentary structures (Fambrini et al. 2005a). Towards the upper portion, a continentalization occurs, being dominated by gravelly bedforms (GB) facies, where channelled deposits are characterized by facies $\mathrm{Gh}, \mathrm{Gp}$ and $\mathrm{Gt}$ with lithofacies of sandstones (Sp, St, Sr, Sh). The roundness and clasts imbrication indicate that the unit was dominated by currents. In addition, four interbedded mudstone levels appear in the upper half of this unit, showing planar stratification and slumped beds, representing mud flows (Fig. 5B). These associations represent shallow to deep, gravel-bed braided river or gravel-bed wandering rivers, or alluvial fans dominated by braided rivers (Miall 2006). Towards the top, in the last $300 \mathrm{~m}, \mathrm{Gcm}$ facies dominate, with debris flow characteristics of alluvial fans. The facies transition involves a change in the depositional regime with nearby source area, involving active tectonic processes.

\section{Calcareous Conglomerate Member}

This unit is a calcareous clast-supported diamictite (an inequigranular conglomerate sensu Eyles et al. 1983, Lamar
1992, Ramírez 1998, Blikra \& Nemec 1998, Bogs 2009, Elswick \& Johnson 2010), with chaotic distribution of the fragments, presenting clasts angular to sub-rounded from pebble size to block size $(>70 \mathrm{~cm}$ ) and sandy matrix (Fig. 9). At the South, this unit overlies the Arkosic Conglomerate Member in conformity and part of the Taruman Lithodeme in angular unconformity. At the North, it overlies the Polanco Marbles in angular unconformity, although in some areas appear to be in para-conformity due to the folding of the Polanco Marbles. This member reaches a mean of 200-m thick, layers are roughly oriented at $330^{\circ} / 20^{\circ}$ being folded at the East in their northern and southern limits. The clast-composition is dominantly marbles, although some clasts of quartz, schist, mylonite, granite and syenite are observed. Three types of calcareous clasts can be identified gray, yellow and pink (Gaucher 2000), being commonly banded and with the presence of quartz veins and chert levels, frequently showing faults and folding. The sandy matrix consists of sand size particles mainly composed by carbonates and in lesser extent quartz, rich in calcareous cement and it has reddish color (moderate red 5R 4/6).
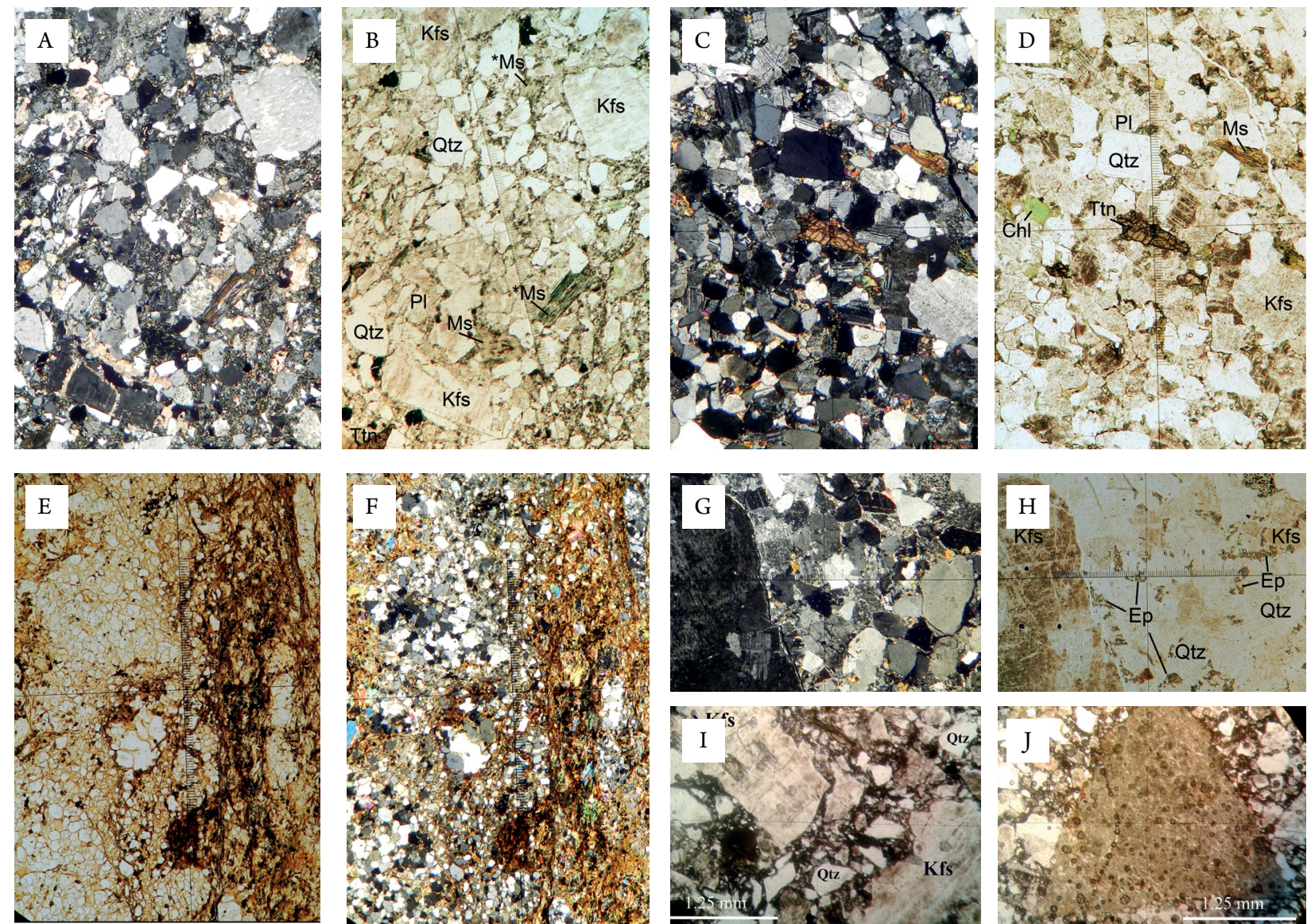

Chl: chlorite; Ep: epidote; Kfs: potassic feldspars; Ms: detritic mica; *Ms: metamorphic mica; Pl: plagioclase; Qtz: quartz; Ttn: titanite.

Figure 8. (A) and (B) Thin section of a meta-arkose sample, in plane polarized light and normal light. Metamorphic and chloritized micas, saussuritization of Ca-plagioclase, serpentinization can be observed. Clast are cut by carbonate-filled post-sedimentary fractures and hollows. (C) and D) Thin section of a meta-arkose sample, in crossed polarizer and normal light. (E) and (F) Thin section of a meta-arkose sample, in plane polarized and normal light. Quartz grains are well selected with $0.5 \mathrm{~mm}$ mean size, concave-convex contacts and incipient triple unions. Sample is heavily fractured, with incipient cataclasis. $(\mathrm{G})$ and $(\mathrm{H})$ Thin section of a meta-arkose sample, in plane polarized and normal light. It is a clast supported rock, with angulate and rounded grains, sand-gravel size clasts. Grain contacts are irregular to concave-convex, with contact deformation and fracturation. Epidote is concentrated in the scarce matrix. (I) Thin section of the basal conglomerate in normal light, composed by syenite clasts, feldspar, plagioclase, quartz, opaque and volcanic clast (see Figs. 5C and 5D). (J) Thin section of the basal conglomerate showing volcanic angulate clasts (see Fig. 5C). All scales in the images has $2.5 \mathrm{~mm}$. 
Table 2. Lithofacies code used in this work after Miall (2006).

\begin{tabular}{|c|c|c|}
\hline $\begin{array}{l}\text { Facies } \\
\text { code }\end{array}$ & Facies & $\begin{array}{l}\text { Sedimentary } \\
\text { structures }\end{array}$ \\
\hline GB & Facies $\mathrm{Gm}, \mathrm{Gp}$ and $\mathrm{Gt}$ & \\
\hline Gh & $\begin{array}{l}\text { Clast-supported, } \\
\text { crudely bedded gravel }\end{array}$ & $\begin{array}{l}\text { Horizontal bedding, } \\
\text { imbrication }\end{array}$ \\
\hline Gp & Gravel, stratified & Planar crossbeds \\
\hline Gt & Gravel, stratified & Trough crossbeds \\
\hline $\mathrm{Gcm}$ & $\begin{array}{l}\text { Clast-supported } \\
\text { massive gravel }\end{array}$ & \\
\hline Gci & Clast-supported gravel & Inverse grading \\
\hline $\mathrm{Gmm}$ & $\begin{array}{l}\text { Matrix-supported, } \\
\text { massive gravel }\end{array}$ & Weak grading \\
\hline Gmg & Matrix-supported gravel & $\begin{array}{l}\text { Inverse to normal } \\
\text { grading }\end{array}$ \\
\hline SB & $\begin{array}{c}\text { Facies: } \mathrm{St}, \mathrm{Sp}, \mathrm{Sh}, \mathrm{Sl}, \mathrm{Sr} \text {, } \\
\text { Se and } \mathrm{Ss}\end{array}$ & \\
\hline Sm & Sand, fine to coarse & $\begin{array}{l}\text { Massive, or faint } \\
\text { lamination }\end{array}$ \\
\hline $\mathrm{Sp}$ & $\begin{array}{l}\text { Sand, fine to very } \\
\text { coarse, may be pebbly }\end{array}$ & $\begin{array}{l}\text { Solitary or grouped } \\
\text { planar crossbeds }\end{array}$ \\
\hline St & $\begin{array}{l}\text { Sand, fine to very } \\
\text { coarse, may be pebbly }\end{array}$ & $\begin{array}{l}\text { Solitary or grouped } \\
\text { trough crossbeds }\end{array}$ \\
\hline Sr & Sand, very fine to coarse & Ripple cross-lamination \\
\hline $\mathrm{Sh}$ & $\begin{array}{l}\text { Sand, v. fine to coarse, } \\
\text { may be pebbly }\end{array}$ & $\begin{array}{c}\text { Horizontal lamination } \\
\text { parting or streaming } \\
\text { lineation }\end{array}$ \\
\hline Sl & $\begin{array}{l}\text { Sand, v. fine to coarse, } \\
\text { may be pebbly }\end{array}$ & $\begin{array}{c}\text { Low-angle }\left(<15^{\circ}\right) \\
\text { crossbeds }\end{array}$ \\
\hline $\mathrm{FF}$ & Facies: $0 \mathrm{Fm}$ and $\mathrm{Fl}$ & \\
\hline $\mathrm{Fm}$ & Mud, silt & $\begin{array}{l}\text { Massive, desiccation } \\
\text { cracks }\end{array}$ \\
\hline $\mathrm{fl}$ & Sand, silt, mud & $\begin{array}{l}\text { Fine lamination, very } \\
\text { small ripples }\end{array}$ \\
\hline
\end{tabular}

This calcareous unit is characterized by Gcm or Gci lithofacies, disorganized, poorly sorted, mass-wasting colluvial deposits ( $c f$. Blikra \& Nemec 1998) and marks a strong lithological, sedimentary and tectonic discontinuity.

\section{Petromictic Conglomerate Member}

This member crops out in the northeast of the study area constituted by a clast-supported conglomerate, with chaotic distribution, pebble to block sized clasts with up to 1 meter in diameter (Fig. 10). To the top of the unit, the grain size decreases gradually, passing from a boulder-conglomerate to a pebble-conglomerate with increase of SB facies (Fig. 11). At least four arkose and mudstones levels occur interbedded in this unit. Moreover, sand beds with decimetric intraclasts, slumps and convolute bedding are observed locally (Figs. 10E and 10F) as it was noted previously (Fambrini et al. 2005a, Preciozzi \& Fay 1988, Fragoso-Cesar et al. 1987). This unit reach a maximum of 1,650 m (see profile AA' in Fig. 4). At the West, this member overlies the Calcareous Conglomerate Member in conformity or paraconformity. At the East and South, it overlies in nonconformity gneisses and the Taruman Lithodeme, at the Nort and Northwest, it is in fault contact with the Polanco Marbles. Near the Vidal's old ranch, arkoses and mudstones overlies the basement with subhorizontal dip (Figs. 4 and 12). A description with two profiles and provenance analysis of this member can be found in Gaucher (2000) (see Fig. 4).

The lower part of this member is dominated by massive conglomerates with decimeter to meter tabular stratification, and preferential $\mathrm{N} 22^{\circ}$ trends. Pebble-conglomerates tend to be more rounded, with scarce matrix, fhowing massive and lenticular stratification geometry (Fambrini et al. 2005a). Fining-andthinning-upward trend predominates, even coarsening upwards are observed, as it is noted in previous works (Gaucher 2000, Fambrini et al. 2005a). Clast-composition includes granites, gneisses, mylonites, quartzites, shales, and calcareous (Figs. $10 \mathrm{~A}$ and $10 \mathrm{~B}$ ). Its matrix is sandy, gray to reddish color, and intergranular interstices are occupied by siliceous cement (Fig. 10A). Often, centimetric to decimetric thick sandstones are interbedded to the conglomerate (Figs. 10C and 10D). They
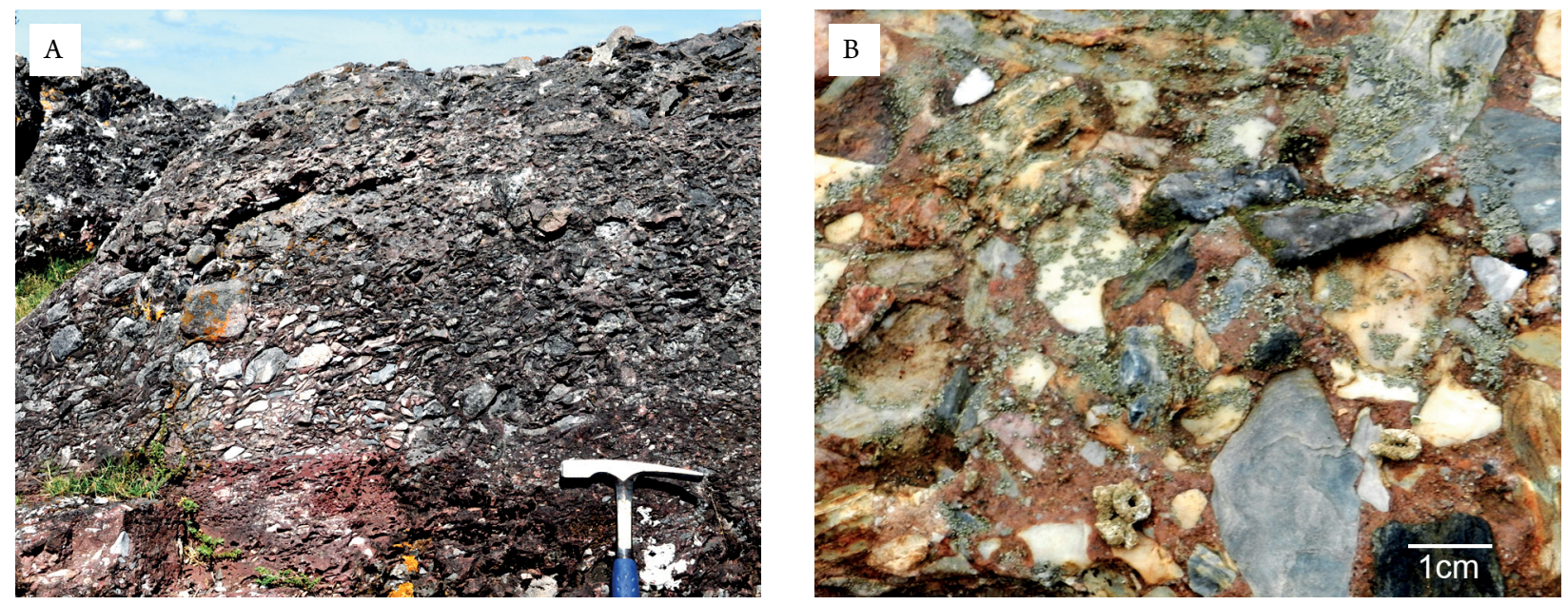

Figure 9. Macroscopic features of the calcareous conglomerate member rocks. Pebble to cobble size conglomerates, clasts are mainly composed of marbles, matrix is composed of sand size particles. 
can be classified as coarse to medium arenites with disperse clasts and massive to planar stratification.

The upper part of Barriga Negra Formation occurs nearly Vidal's old ranch, with an apparent thickness of up to $400 \mathrm{~m}$
(Figs. 4 and 11). Lithologically, this is fine- to medium-size arkosic levels and decimetric to metric mudstones, commonly of reddish colors (dusky red 5R 3/4), although gray and greenish (moderate yellowish green 10Gy 6/4) also
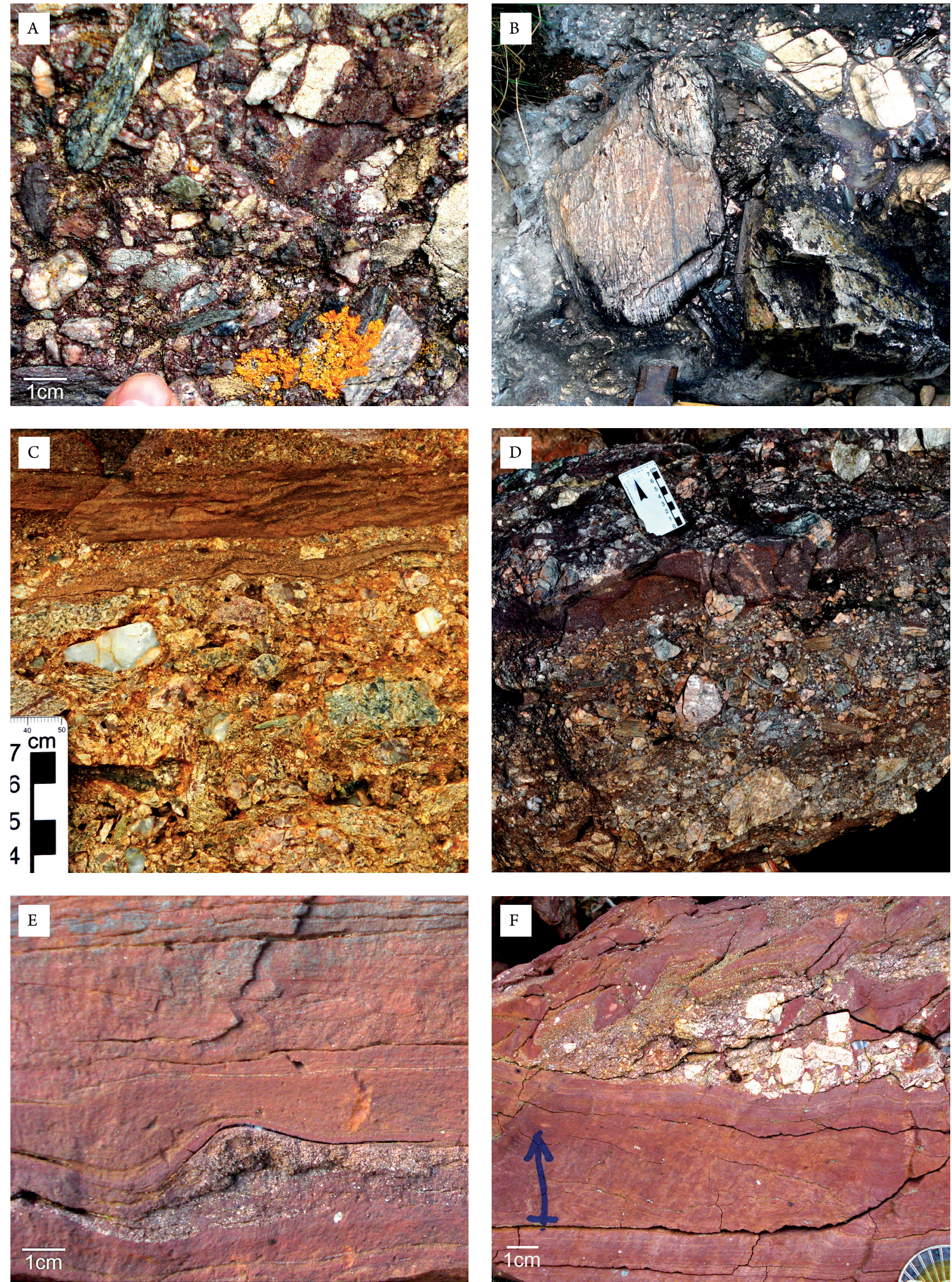

Figure 10. Petromictic conglomerate member: (A) detail of the conglomerate matrix with clast of schists, gneisses, mylonites, granitoids and quartzites; (B) basal conglomerates with clasts of gneisses, mylonites and marbles; (C) and (D) psammitic levels; (E) and (F) slumped beds, convolute lamination and liquefaction structures due detrital flows. 
are present (Fig. 11). Commonly, they occur interspersed by millimetric levels of coarse sand, granule-conglomerates, and scattered clasts. Micaceous sandstones levels are also common (Preciozzi \& Fay 1988). The plane-parallel stratification is dominant. Near Vidal's old ranch commonly occurs ripple marks, drying shrinkage cracks (Fig. 11, Walther 1919, Fragoso-Cesar et al. 1987, Díaz et al. 1990) and preservation of raindrops (Fig. 11B). Mud-cracks warps upward at the margins and might imply that they were formed in fresh water ( $c f$. Kindle 1917, Baria 1977, Plummer \& Gostin 1981). Bedding-planes usually dips $7^{\circ}$ to $20^{\circ}$ towards the $\mathrm{E}$. This upper level preserves characteristics of alluvial fan deposits dominated by currents due to the scarcity of mudflows facies Gmm, Gmg and Sm. The scarcity of these mudflows is considered as an indicator of an arid environment. Towards the top, fluvial signatures with SB facies and appearance of Sr, Sl, and FF (Fl and Fm) facies reacquire. The presence of desiccation cracks at higher levels (Fm) confirms, in turn, aridity conditions.

\section{Basement and structural controls}

The basement of the Barriga Negra Formation consists of various lithotectonic associations corresponding to different ages. The basement outcrops to the east and consists of deformed granites, gneisses, muscovite schists, mylonites and BIF's, trending to N-NE with subvertical foliation. At the south-east subjacent to Barriga Negra Formation, a succession of foliated and folded marbles, calcareous phyllites, meta-sandstones, very mature and deformed quartz conglomerates and massive quartzites named Taruman Lithodeme outcrops (Núñez Demarco 2014).

The north and western basement is made up of two interbedded and folded units:

1. Polanco Marbles (Goñi \& Hoffstetter 1964, Sánchez Bettucci et al. 2010b, Núñez Demarco 2014, among others);

2. de los Bueyes Quartzites (Núñez Demarco 2014).

The first one is composed by marbles, impure marbles and calc-silicate schist rocks; the second one is represented by massive quartzites and mature meta-sandstones (Figs. 4, 12 and 13). Both basement units are considered here as part of the Lavalleja Group (Sánchez Bettucci et al.2001, 2010a), but they were also mapped as part of Las Tetas Complex (Hartmann et al. 2001; Fig. 2).

The gneissic basement, Taruman Lithodeme and Polanco Marbles are equivalent to the Las Tetas Complex (Hartmann
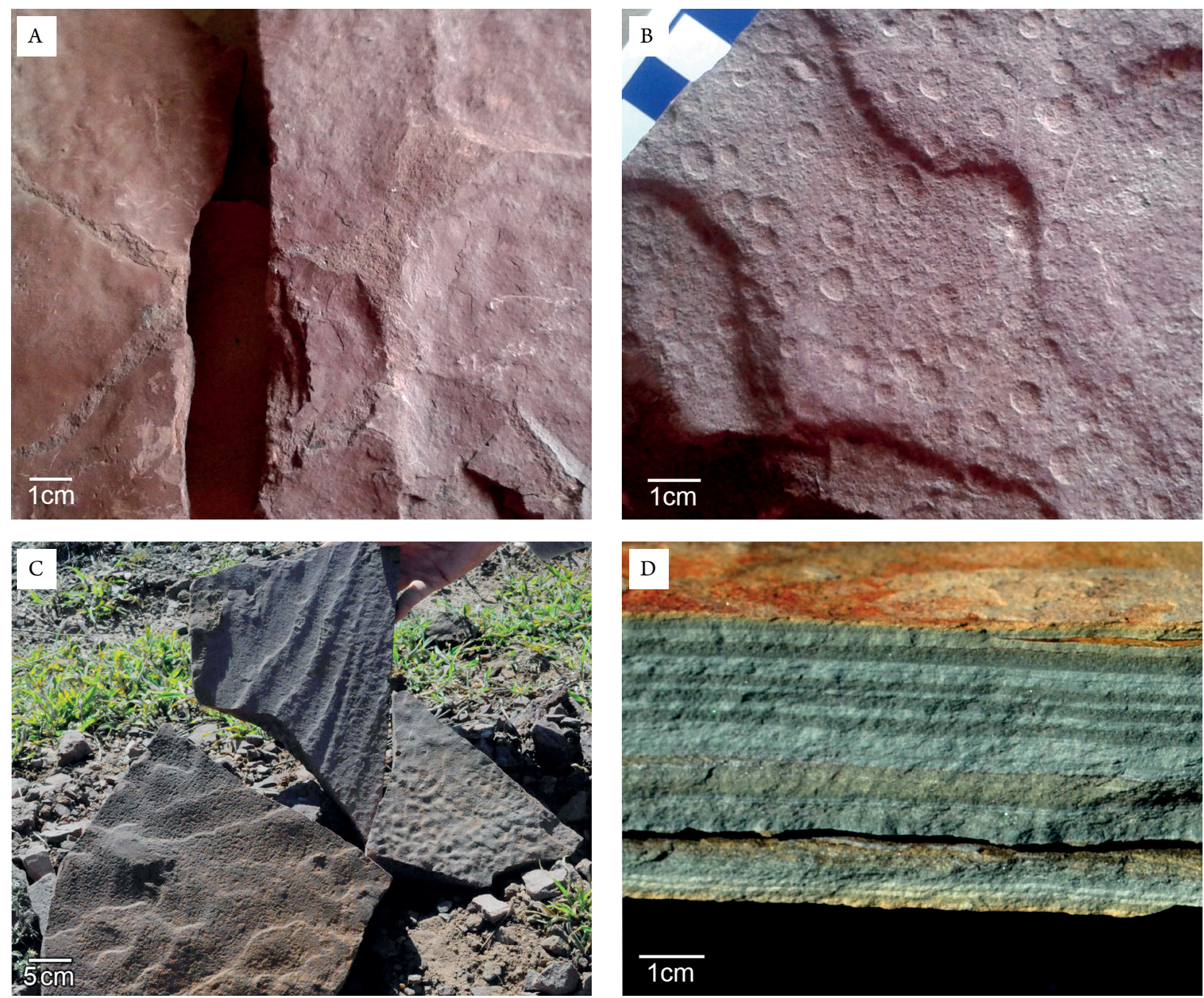

Figure 11. Structures in the petromictic conglomerate member uppermost levels: (A) desiccation cracks; (B) preserved water drops and ripples in red-colored levels; (C) different preserved ripples in psammites as well as "wrinkle" structures; (D) planar bedding and cross lamination in green colored slate levels. 
et al. 2001), of Archean age (Figs. 2, 4 and 13), and affected by greenschist to amphibolite facies metamorphism. In the southern portion of the study area, the Doña Eustaquia Syenite crops out (Núñez Demarco 2014). This body is contiguous to two granitic complexes (see Fig. 2). Hence, it could belong either to the Polanco Granitic Complex (Preciozzi et al. 1981) with and Rb-Sr age of $548 \pm 15 \mathrm{Ma}$ (Umpierre \& Halpern 1971, Bossi et al. 1998) and U-Pb zircon age of $586 \pm 11 \mathrm{Ma}$ (Bossi \& Gaucher 2014), or to the Santa Lucia Batholith (Bossi et al. 1998) with U-Pb sensitive high resolution ion microprobe (SHRIMP) ages of crystallization at $633 \pm 8 \mathrm{Ma}$ and metamorphism at $607 \pm 7 \mathrm{Ma}$ (Hartmann et al. 2002).

The relationship between the basement and the Barriga Negra Formation is erosional unconformities or tectonics (fault contacts). The Barriga Negra graben was controlled by a NS-fault at the East that turns to a northeast-southwest direction at the North, and by a northeast-southwest fault at its southern limit, parallel to the northern fault. The folding to east, at the North and South borders, may suggest post sedimentary compression of the basin. Westwards, the sequence is cut by a NS fault, being in angular unconformity with the Polanco Marbles and the Cerro de los Bueyes Quartzites. However, in the proximities of the fault zone, the Polanco Marbles are sometimes in structural para-conformity due to a drag folding (Figs. 4, 12 and 13). Near this fault and related ones, hydrothermal metamorphism and strong silicification in the Barriga Negra Formation are observed. This formation has not continuity with any other sedimentary or metamorphic sequence, and particularly there are no contact nor direct relationship with any other unit of the Arroyo del Soldado Group. In the southern border of the type-locality, it is possible to recognize the metamorphic contact of the Polanco Marbles with the Doña Eustaquia Syenite, and the verticalized Barriga Negra Formation. Furthermore, important hydrothermal (e.g., $\mathrm{Cu}$-mineralized quartz) mineralization occur along this fault system. On the other hand, rhyolitic dikes in the South border of the Barriga Negra Formation is controlled by graben faults. These dikes could be related to the Cretaceous Arequita Formation - related to the Mesozoic rifting - , suggesting that this tectonic activity may be related to the reactivation, hydrothermal alteration and compression of the graben.

\section{DISCUSSION AND CONCLUSIONS}

The Barriga Negra Formation is composed of well-preserved immature conglomerates and sands rich in feldspar and lithic fragments. As several authors have already noted, the preservation of large amounts of feldspar, mica, and carbonates during the weathering may be related to very arid conditions, or humid environments with a very sharp relief to allow rapid erosion and burial of the clasts

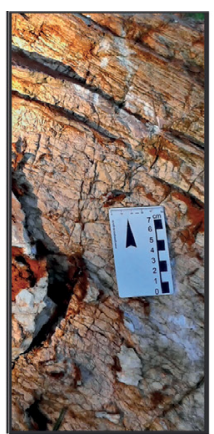

A

A

Barriga Negra stream
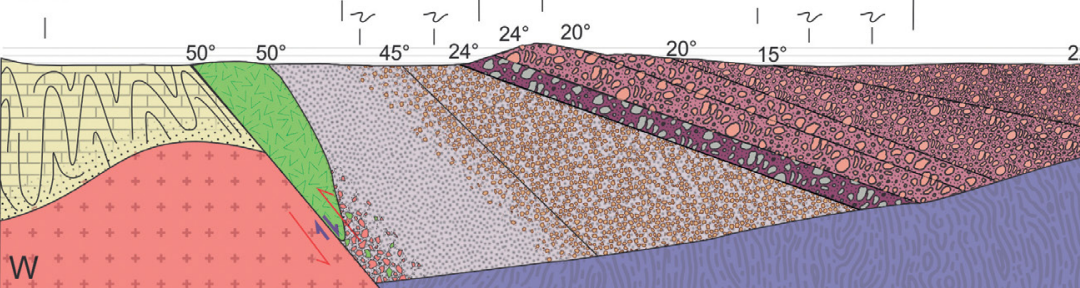

Figure 12. Section A-A' in profile and map of Figure 4. Conglomerates pattern was adjusted to reflect main granulometric trend. (A) Polanco marbles. (B) Vacuolar volcanic rocks. (C) Granule to pebble size arkosic conglomerates. (D) Calcareous conglomerate. (E) Basal conglomerates with clasts of gneisses, mylonites and marbles. (F) Arenites and granule conglomeratic levels. (G) Gneisses. Color references as in Figure 4. Distance and topography are in the same scale, units' depth is inferred. (1) Contact metamorphism in Polanco Marbles; (2) arkosic conglomerate member basal level composed of syenite and volcanic clasts; (3) Neoproterozoic extensional movements; (4) Neoproterozoic and/or Mesozoic compressive movements; (5) slump levels, see profile in Figure 4. Color scheme as in Figure 4. 
before they can decompose (Bogs 2009, Pettijohn 1949). Clast maturity, size, composition, and detrital zircon ages indicate a clear provenience of the surrounding basement (Gaucher 2000, Fambrini et al. 2005a, Núñez Demarco 2014). The Arkosic Conglomerate Member is composed mainly by fragments of Neoproterozoic syenites and leucogranites outcropping at the South (Doña Eustaqui Sienite, Santa Lucia Batholith) and only in lesser extend by volcanic rocks, marbles and other lithic fragments (Fambrini et al. 2005a, Nuñez Demarco 2014) consistent with the paleo current directions WNW. The Calcareous Conglomerate Member is composed almost entirely by clast from the Polanco Marbles (Gaucher 2000, Núñez Demarco 2014). The Petromictic Conglomerate Member is composed of lithic fragments, mainly medium- to high-degree metamorphic rocks (mylonites, gneisses, schists), that outcrops only at the East and North of the basin and from Neoproterozoic granitoids located at the South, East and North-East of the area (Figs. 1, 2 and 13, Nuñez Demarco 2014). In all the previous works (Midot 1984, Gaucher 2000, Fambrini et al. 2005a, among others), the Calcareous Conglomerate Member was believed to be the base of the Barriga Negra formation, and the Arkosic Conglomerate Member was supposed overlying it, being one with Petromictic Conglomerate Member. However, according to the new revealed stratigraphy, this member cannot be interpreted as the simple cannibalization of the basin basement as in previous works. The appearance of calcareous clasts and the disappearance of quartz-feldspar clasts imply an input area change and may represent a significant hiatus. The increase in the clasts size, also, sets a change in depositional regime, pointing to a rapid increase in the morphological gradients near the basin, involving an active tectonics phenomenon (Lamar 1992, Blikra \& Nemec 1998, Ramírez 1998, Bogs 2009, Elswick \& Johnson 2010). According to Gaucher (2000), this unit represents five depositional events. Each of these diamictite deposits suggests an estimated period of hundreds to thousands of years between each deposit or a sudden tectonic event (sensu Miall 2006), implying a significant hiatus in the sedimentary input and/or a significant tectonic event.

The new mapping identifies that locally the bottom of the sequence is represented by volcanic rocks as stated above (Figs. 5A, 11 and 12). The presence of volcanic rocks and gravity flows and clast composition and size changes indicate active tectonics conditions during the deposition characterized by faulting and unstable slopes. Barriga Negra
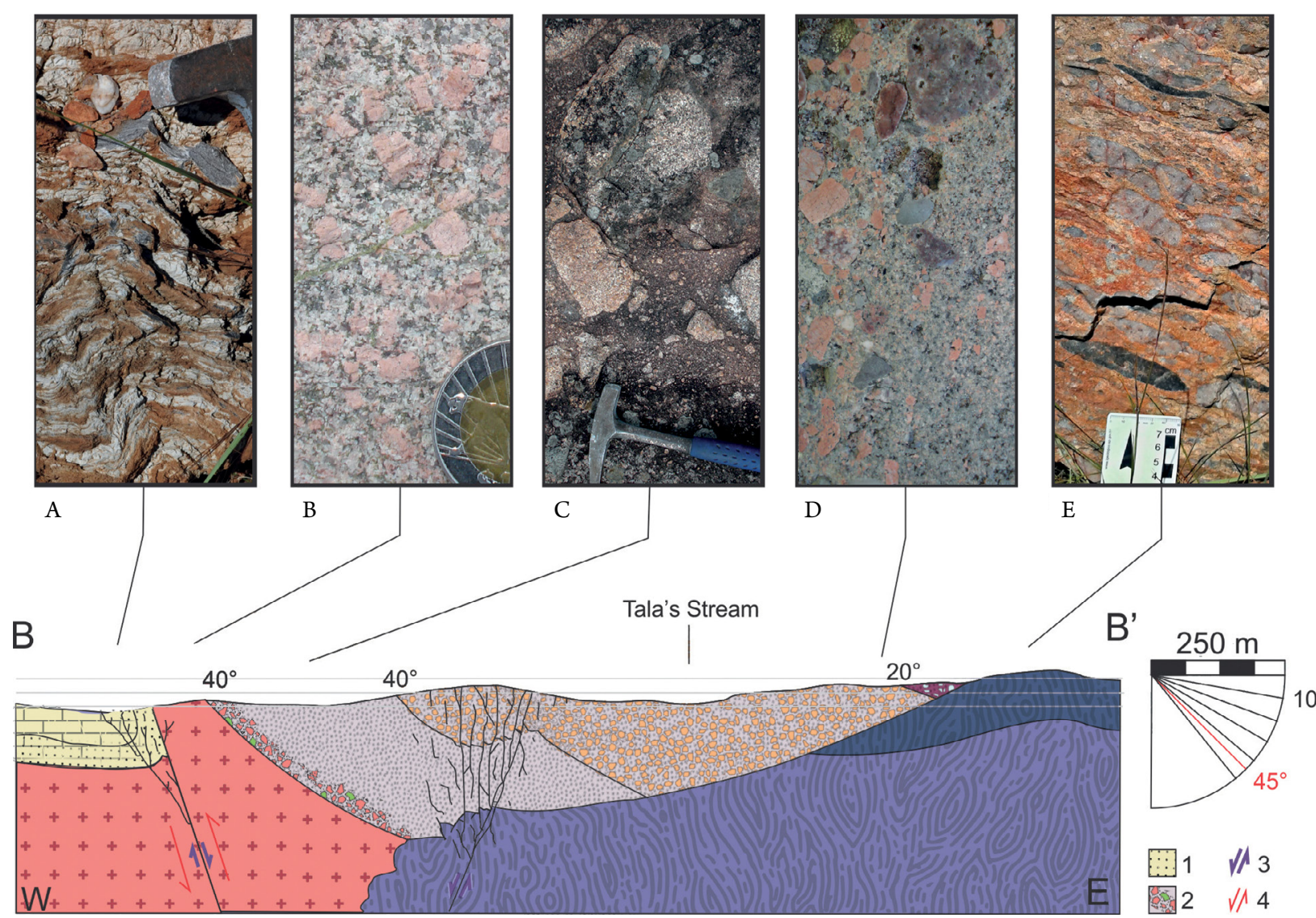

Figure 13. Section B-B' in map of Figure 4. (A) Polanco marbles. (B) Doña Eustaquia Syenite. (C) Basal conglomerate composed by syenite and volcanic clasts at the bottom of the arkosic conglomerate member. (D) Pebble-size conglomerates at the top of the arkosic conglomerate member. (E) Deformed conglomerates of the Taruman Lithodeme. Color references as in Figure 4. Distance and topography are in the same scale, unit depth is inferred. (1) Contact metamorphism in Polanco Marbles; (2) arkosic conglomerate member basal level composed of syenite and volcanic clasts; (3) Neoproterozoic extensional movements; (4) Neoproterozoic and/or Mesozoic compressive movements. Color scheme as in Figure 4. 
Formation represents a continental conglomeratic sequence in an active tectonic environment (pull-apart, rift- basin), comprising a volcanic unit and basal conglomerates followed by a coastal deltaic sequence with subsequent continentalization, with colluvial fans evolving towards a system of braided rivers.

Some authors consider the color of Barriga Negra Formation as primary (Fay \& Arrighetti 1981, Gaucher 2000). Field observations suggest that the color variations from gray-green to dark purple (ferrification) on the same shale level (see Fig. 11) are probably due to alteration phenomena after sedimentation, and possibly after consolidation (post-diagenetic). Cenozoic ferrification events, noted in other regions of Uruguay, may be responsible for the current color formation (Ford \& Gancio 1988, Bossi et al. 1998, Rapalini \& Bettucci 2008, Tófalo \& Morrás 2009).

According to Gaucher et al. (2008) and Blanco et al. (2009), the age of Barriga Negra Formation is between $583 \pm 7$ and $532 \pm 11 \mathrm{Ma}$, supported by stratigraphic relations of the Arroyo del Soldado Group with granitic bodies (see Fig. 2, Mangacha Granite sensu Bossi \& Gaucher 2014). However, as this work shows, this unit has no continuity nor contacts with other sedimentary units, so age constraints based in its stratigraphic continuity are no longer applicable.

In addition, Gaucher (2000) and Gaucher et al. (2003) suggested an Ediacaran age for the sequence based on the presence of microfossils Cloudina $(<550 \mathrm{Ma})$ in the upper units, while populations of show ages from 3400 to $566 \pm$ $8 \mathrm{Ma}$ (Blanco et al. 2009). However, Aubet et al. (2014) warned that the microfossils found are poorly preserved and that their identification is inaccurate. Also, according to Zhuravlev et al. (2012), the described fossils in Uruguay (Gaucher \& Sprechmann 1999, Gaucher et al. 2003) require further study since it is unlikely to be cloudinids. Moreover, it is noteworthy that Neoproterozoic fauna containing the Cloudina assemblage was reported in carbonate platform deposits of the Nama Group (Pickford 1995, Grotzinger et al. 2000) and is identified in the underlying, discordant and metamorphosed Polanco Marbles, suggesting contamination by reworking of the basal units.

Gaucher (2000) and Bossi \& Gaucher (2014) also highlights the presence of glauconite (formed in marine settings and commonly associated with low-oxygen conditions) and Bavlinella faveolata species (marine) at the top of the sequence (top of Petromictic Conglomerate Member). Glauconite minerals were not find in our work, but metamorphic assemblages are common (see Fig. 8). Furthermore, the association of lithofacies at the top of the unit (ripples, water drops, mud cracks, etc.) indicates a freshwater fluvial and arid continental palaeoenvironment, making highly unlikely the presence of glauconite or Bavlinella. Although the precise place of this glauconite/Bavlinella bearing level is not indicated (Gaucher 2000, Fig. 2, point 15), it was indicated that Bavlinella occurs

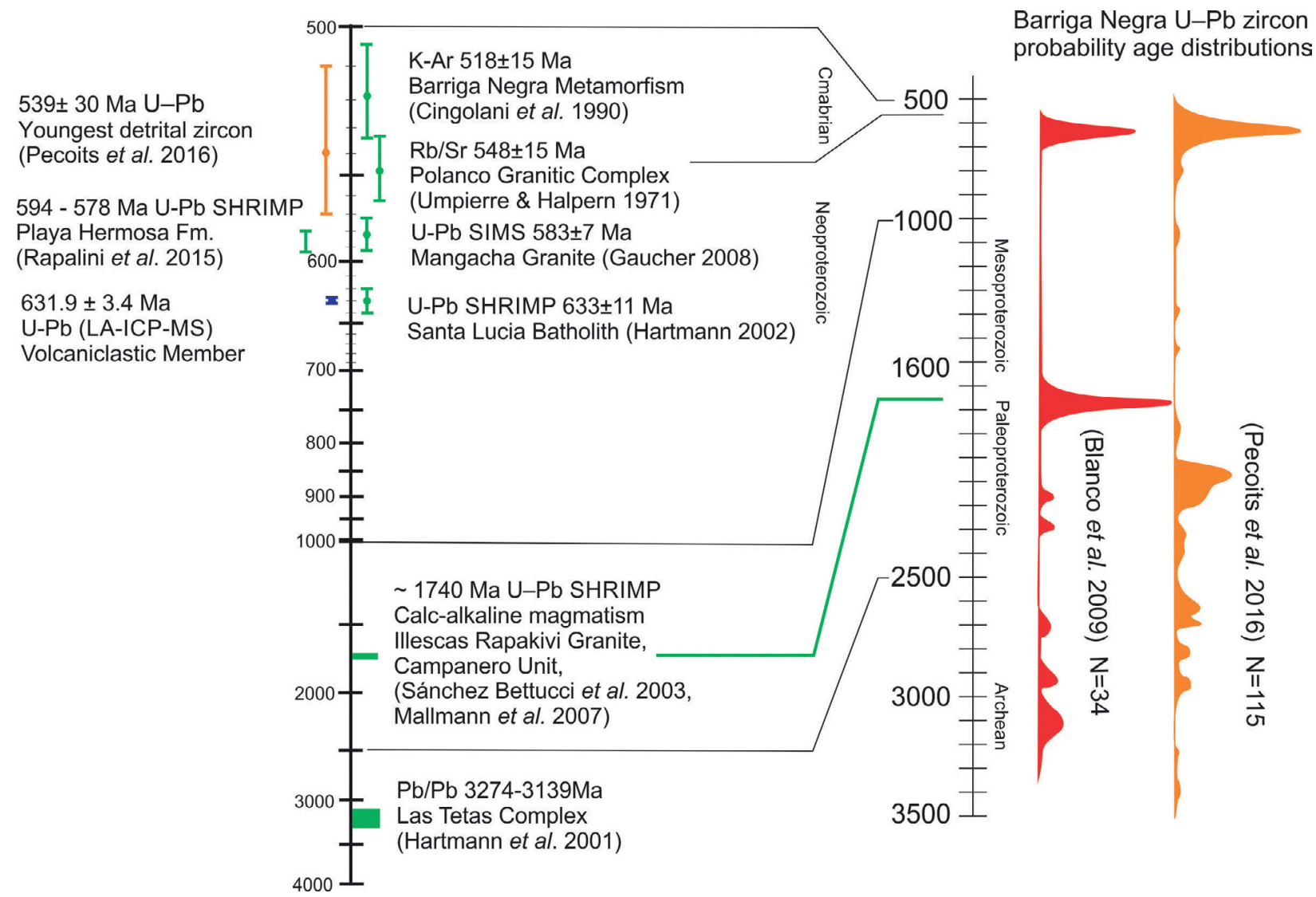

SHRIMP: sensitive high resolution ion microprobe; Fm.: formation; LA-ICP-MS: laser ablation inductively coupled plasma mass spectrometry; SIMS: secondary ion mass spectrometry.

Figure 14. Detrital zircon ages of the Barriga Negra Formation and related regional units ages. 
in association with iron-rich shales and BIF, but the shales in Barriga Negra Formation present a clear secondary oxidation, and the BIF in the area belongs to the metamorphic basement. In addition, the mentioned ferrification of this unit makes the palynological studies difficult.

On other hand, Cingolani et al. (1990) dated metapelites from the Clastic Member of the Barriga Negra Formation by $\mathrm{K}-\mathrm{Ar}$ method obtaining an age of $518 \pm 15$. These authors interpret this age related to metamorphic or tectonothermal events during the Brasiliano Orogenic Cycle.

Detrital zircon ages of Barriga Negra Formation are presented by Blanco et al. (2009) $\mathrm{N}=34$ and Pecoits et al. (2016) $\mathrm{N}=115$, yielding ages between the Archean and Neoproterozoic (see Fig. 14) reflecting ages of the basement rocks well known in the region (Oyhantçabal et al. 2010). According to Pecoits et al. (2016), the mean age of the youngest zircon population is $\sim 581 \pm 6 \mathrm{Ma}$, while the youngest zircon yield and age of $539 \pm 30 \mathrm{Ma}$. Considering this data, the end of the sedimentation in Barriga Negra Formation can be roughly constrained between the youngest depositional age given by age of the youngest detrital zircon $(539 \pm 30 \mathrm{Ma})$, and the age of the metamorphic event ( $518 \pm 15 \mathrm{Ma})$. The beginning of sedimentation can be constrained by the age of the volcanic rocks (631.9 \pm 3.4 Ma) at the base of Barriga Negra Formation.

Some authors sustain that the Barriga Negra Formation is part of the Arroyo del Soldado Group and it is correlated with the Corumbá (Brazil) and Sierra Bayas (Argentina) groups (Gaucher 2000, Gaucher et al. 2003, Blanco et al. 2009, Bossi \& Gaucher 2014). For these authors, these groups represent Ediacaran-Cambrian marine deposits in a transitional passive margin, in which Barriga Negra Formation is located either at the middle portion or at the base of the stratigraphic profiles and was interpreted as continental deposits in transition to a marine environment at the top (Gaucher 2000, Blanco et al. 2009, Bossi \& Gaucher 2014, Aubet et al. 2014). However, Barriga Negra has no stratigraphic continuity to any other Arroyo del Soldado unit, and its lithology, facies and palaeoenvironment are not consistent with any other unit in the group. According to the International Stratigraphic Code, a group is "a sequence of two or more contiguous or associated formations with significant and diagnostic lithologic properties in common" (sections 5.C.6 and 5.D.3, Salvador 1994). Therefore, in basis of the present evidence, the unit cannot be included in the Arroyo del Soldado Group.

The Barriga Negra Formation has historically been interpreted as an intermountain molassic basin related to the final stages of Brasiliano orogenic cycle (Bossi et al. 1975, Preciozzi et al. 1979, Fragoso-Cesar et al. 1987). However, Fambrini et al. (2005a) and Almeida et al. (2010) suggested that Barriga Negra formation correlates with the Santa Barbara Group of Brazil, part of the Camaquã basin (Fragoso Cesar et al. 2000). The Santa Barbara Group is characterized by an alluvial-fans and fluvial continental sequences generated in a system of pull-apart transcurrent basins in a late- to post-orogenic context, according NW-SE trending extension, during the Ediacaran-Cambrian period (Fambrini et al. 2005b, Janikian et al. 2008. On the other hand, Midot (1984) considered in his maps other minor occurrences of the Barriga Negra Formation near the Minas city as El Perdido and the Las Palmas hills. Sánchez Bettucci (1998) and Sánchez Bettucci et al. (2003) reinterpreted the Las Palmas outcrops Mesozoic volcaniclastic deposits. By using the microstructures found in pelites, Masquelin et al. (2017) argued that El Perdido hill outcrop represents the same lithofacies than the reddish conglomerates, sandstones and shales of the Barriga Negra stratotype, but affected by NE-SW oriented slaty and pencil cleavage, which cannot correspond to the expected tectonic environment of the Santa Lucía-Aiguá-Merin rift (Rossello et al. 1999). Furthermore, the Las Palmas conglomerate, which overlays the stromatolitic marbles in the Mina Verdún quarry, is cut by dolerite dykes, yielding a K-Ar age of ca. 485 Ma (González et al. 2004). Other areas previously indicated as Barriga Negra at the North were only presented in geological sketches (Fig. 3) without map, stratigraphy nor precise location.

On other hand, Midot (1984) describes another volcanic and conglomeratic unit at the south of Uruguay named Las Ventanas Formation (Midot 1984). The units were not correlated, because it was believed that Barriga Negra Formation was sub-horizontal, undeformed and had no volcanic rocks or volcanic clasts (Midot 1984, Bossi \& Navarro 1991, Blanco et al.2010). However, according to the stratigraphy and lithological description presented in this work, both units can be correlated (as it was previously suggested by Sánchez Bettucci et al. 2010b). Las Ventanas Formation is grouped with other Neoproterozoic molassic deposits at the south of Uruguay in Playa Verde Basin (Masquelin \& Sánchez-Bettucci 1993, Sánchez Bettucci \& Pazos 1996, Pazos et al. 2003). From base to top, this basin includes the Playa Hermosa, San Carlos and Las Ventanas Formations (Masquelin \& Sánchez Bettucci 1993, Masquelin 1990, Midot 1984, Rapalini et al. 2015) in which was recorded an interaction of extensional faulting and cold arid climate (glaciation) in a tectonically active basin with locally high subsidence rates (Pazos et al. 2003, 2008). Also, an alternative proposal suggested by Pecoits et al. (2016) puts together Las Ventanas and Barriga Negra Formations in the Maldonado Group.

In a regional context, Las Ventanas Formation was correlated with the Guaritas Formation, in Brazil (FragosoCesar et al. 1987, Masquelin \& Sánchez-Bettucci 1993, Pazos et al. 2003). However, radiometric data indicate that the Guaritas Formation has $535 \mathrm{Ma}$ (Almeida et al.2010), while Las Ventanas Formation ranges 594 and $578 \mathrm{Ma}$ (Rapalini et al. 2015). The volcanic units under Santa Barbara Group: Acampamento Velho Formation shows ages $574 \pm 4$ (Ar-Ar) and Bom Jardim Group presents ages around $601 \mathrm{Ma}$ (Janikian et al. 2008), concordant with the observed ages in Las Ventanas and Barriga Negra formations, making the correlation between these units the most plausible 
option. Furthermore, these Brazilian and Uruguayan units were deposited in continental environments, under active extensional tectonism, spanning the time of the Gaskiers Glaciation and ending of Marinoan/Varanger Glaciation (Pazos et al. 2003, 2008, Janikian et al. 2008).

Finally, it is proposed here a new stratigraphy for the Barriga Negra Formation based on detailed field work, petrography, and structural relationships. This formation is divided into four members, from bottom to top:

1. Volcaniclastic Member;

2. Arkosic Conglomerate Member;

3. Calcareous Conglomerate Member;

4. Petromictic Conglomerate Member.

This succession represents a continental conglomeratic sequence developed in arid and active tectonic environment (rift-basin) deposited after $632 \mathrm{Ma}$. The relationships between the basement and the Barriga Negra Formation are either erosional unconformities or fault contacts. Different basement rock-successions locate under the Barriga Negra Formation, including orthogneisses and low-grade metamorphic marbles, schists, metaconglomerates and quartzites, which represent Archean to Neoproterozoic metamorphic series. Also, Neoproterozoic and Mesozoic tectonic events affected the unit showed by ductile deformation and regional and hydrothermal metamorphism. The last event that affected this unit corresponds to the Mesozoic extensional event.

\section{ACKNOWLEDGEMENTS}

We are particularly grateful to Natalia Porta and Daniel Picchi for the thin section preparation. We thank the Comisión Sectorial de Investigación Científica (CSIC) to provide funds for the field-work, and Programa de Desarrollo de las Ciencias Básicas (PEDEClBA) - Geociencias. The reviewers are greatly acknowledged for their detailed review and constructive suggestions, which contributed to the improvement of the final version of the manuscript.

\section{ARTICLE INFORMATION}

Manuscript ID: 20180047. Received on: 04/21/2018. Approved on: 12/04/2018.

P. N. D. and H. M. conducted the investigation, mapping and data acquisition. A. P. N. D. wrote the manuscript, produced the figures, and was responsible for all the measurements and the geological analyses. Authors H. M. and E. P. contributed to the writing and interpretation of the radiometric results. Author L. S. B. conceived the study and with author H. M. supervised the findings of this work. All authors discussed the results and contributed to the final manuscript.

Cometing interests: The authors declare no competing interests.

\section{REFERENCES}

Almeida R.P.D., Janikian L., Fragoso-Cesar A.R.S., Fambrini G.L. 2010. The Ediacaran to Cambrian rift system of Southeastern South America: tectonic implications. The Journal of Geology, 118(2):145-161. https://doi. org/10.1086/649817

Aubet N.R., Pecoits E., Heaman L.M., Veroslavsky G., Gingras M.K., Konhauser K.O. 2014. Ediacaran in Uruguay: Facts and controversies. Journal of South American Earth Sciences, 55:43-57. https://doi. org/10.1016/j.jsames.2014.06.007

Baria L.R. 1977. Desiccation features and the reconstruction of paleosalinities. Journal of Sedimentary Research, 47(2):908-914. https://doi. org/10.1306/212F728E-2B24-11D7-8648000102C1865D

Basei M.A.S., Frimmel H.E., Nutman A.P., Preciozzi F. 2008. West Gondwana amalgamation based on detrital zircon ages from Neoproterozoic Ribeira and Dom Feliciano belts of South America and comparison with coeval sequences from SW Africa. Geological Society, London, Special Publications, 294(1):239256. https://doi.org/10.1144/SP294.13

Basei M.A.S., Frimmel H.E., Nutman A.P., Preciozzi F., Jacob J. 2005. A connection between the Neoproterozoic Dom Feliciano (Brazil/ Uruguay) and Gariep (Namibia/South Africa) orogenic belts evidence from a reconnaissance provenance study. Precambrian Research, 139(3-4):195-221. http://dx.doi.org/10.1016/j. precamres.2005.06.005

Basei M.A.S., Siga Jr. O., Masquelin H., Harara O.M., Reis Neto J.M., Preciozzi F. 2000. The Dom Feliciano Belt (Brazil-Uruguay) and its foreland (Rio de la Plata Craton): Framework, Tectonic Evolution and Correlations with similar terranes of Southwestern Africa. In: Cordani U., Thomaz F., Milani E. (Eds.). Precambrian Evolution of South America. International Geological Congress, Rio de Janeiro: IUGS.
Blanco G., Rajesh H.M., Gaucher C., Germs G.J., Chemale Jr. F. 2009. Provenance of the Arroyo del Soldado Group (Ediacaran to Cambrian, Uruguay): implications for the paleogeographic evolution of southwestern Gondwana. Precambrian Research, 171(1-4):57-73. http://dx.doi. org/10.1016/j.precamres.2009.03.003

Blanco G., Rajesh H.M., Gaucher C., Germs G.J., Chemale Jr. F. 2010. Reply to the comment by Sánchez Bettucci et al. on: "Provenance of the Arroyo del Soldado Group (Ediacaran to Cambrian, Uruguay): Implications for the paleogeographic evolution of southwestern Gondwana" [Precambrian Res. 171 (2009) 57-73]. Precambrian Research, 180(3):334-342. http://dx.doi. org/10.1016/j.precamres.2010.03.009

Blikra L.H., Nemec W. 1998. Postglacial colluvium in western Norway: depositional processes, facies, and palaeoclimate records. Sedimentology, $\mathbf{4 5}(5): 909-959 . \quad \mathrm{https} / /$ doi. org/10.1046/j.1365-3091.1998.00200.x

Bogs S. 2009. Petrology of Sedimentary Rocks. $2^{\text {nd }}$ ed. Cambridge: Cambridge University Press.

Bossi J. 1966. Geología del Uruguay. Montevideo: Departamento de Publicaciones de la Universidad de la República, 469 p. Colección Ciencias, n. 2

Bossi J. \& Campal N. 1992. Magmatismo y tectónica transcurrente durante el Paleozoico inferior del Uruguay. In: Gutiérrez J., Saavedra J., Rábano I. (Eds.). Paleozoico Inferior de Ibero - América. Spain: Universidad de Extremadura, p. 343-356

Bossi J. \& Gaucher C. 2004. The Cuchilla Dionisio Terrane, Uruguay: an allochthonous block accreted in the Cambrian to SW-Gondwana. Gondwana Research, 7(3):661-674. https://doi.org/10.1016/ S1342-937X(05)71054-6 
Bossi J. \& Gaucher C. (Eds.). 2014. Geología del Uruguay: Predevónico. Montevideo: Polo S.A., 450 p. Tomo 1.

Bossi J. \& Navarro R. 1991. Geología del Uruguay. Montevideo: Departamento de Publicaciones de la Universidad de la República, v. 1.

Bossi J., Ferrando L., Fernández A., Elizalde G., Morales H., Ledesma J., Carballo E., Medina E., Ford I., Montaña J. 1975. Memoria de la Carta Geológica del Uruguay, escala 1:1.000.000. Montevideo: Dirección Suelos y Fertilizantes, MAP, $32 \mathrm{p}$.

Bossi J., Ferrando L., Montaña J., Campal N., Morales H., Gancio F., Schipilov A., Piñeyro D., Sprechmann P. 1998. Memoria explicativa de la Carta Geológica del Uruguay a escala 1:500.000. Montevideo: Fac. Agronomía, UdelaR, $122 \mathrm{p}$.

Bossi J., Navarro R., Gaucher C. 2002. Discussão. In: Sanchez L. \& Ramos V. 1999. Aspectos geológicos de las rocas metavolcánicas del Grupo Lavalleja, sudeste de Uruguay. Revista Brasileira de Geociências, 29(4):557-570. Revista Brasileira de Geociências, 32(4):598-604.

Caorsi J. \& Goñi J. 1958. Geología Uruguaya. Boletín del Instituto Geológico del Uruguay, 37:1-73.

Chemale Jr. F. 2000. Evolução geológica do Escudo Sul-rio-grandense. Geologia do Rio Grande do Sul, 13-52.

Chiglino L., Gaucher C., Sial A.N., Bossi J., Ferreira V.P., Pimentel M.M. 2010. Chemostratigraphy of Mesoproterozoic and Neoproterozoic carbonates of the Nico Pérez Terrane, Río de la Plata Craton, Uruguay. Precambrian Research, 182(4):313-336. http://dx.doi.org/10.1016/j. precamres.2010.06.002

Cingolani C., Spoturno J., Bonhomme M. 1990. Resultados mineralógicos y geocronológicos preliminares sobre las unidades piedras de afilar, Lavalleja y Barriga Negra R. O. Uruguay. In: Congreso Uruguayo de Geología, 1. Actas... p. 11-18.

Cosarinsky M. 1997. Geología del sector sur de la región Fuente del Puma, Departamento de Lavalleja, Uruguay. Undergraduate Thesis, Universidad de Buenos Aires, Buenos Aires.

De Santa Ana H. \& Ucha N. 1994. Exploration perspectives and hydrocarbon potential of the Uruguayan sedimentary basins. Montevideo: ANCAP, $98 \mathrm{p}$. (informe interno).

Díaz J., Albanell A., Bossi J. 1990. Memoria explicativa del fotoplano Cerro Partido. Montevideo: Facultad de Agronomía.

Elswick E.R. \& Johnson C.C. 2010. Evaluation of a siliciclastic diamictite from the Maya Mountains of Belize. Journal of South American Earth Sciences, 29(3):676-684. https://doi.org/10.1016/j.jsames.2009.11.005

Eyles N., Eyles C.H., Miall A.D. 1983. Lithofacies types and vertical profile models; an alternative approach to the description and environmental interpretation of glacial diamict and diamictite sequences. Sedimentology, 30(3):393-410. https://doi. org/10.1111/j.1365-3091.1983.tb00679.x

Fambrini G., Fragoso-Cesar A.R.S., Paes de Almeida R., Riccomini C. 2005a. A Formação Barriga Negra (Ediacarano do Uruguai): Caracterização estratigráfica e correlação com unidades do estado do Rio Grande do Sul, Brasil. Revista Brasileira de Geociências, 35(4):515-524.

Fambrini G.L., Janikian L., Almeida R.P., Fragoso-Cesar A.R.S. 2005b. O Grupo Santa Bárbara (Ediacarano) na Sub-Bacia Camaquã Central, RS: estratigrafia e sistemas deposicionais. Revista Brasileira de Geociências, 35(2):227-238.

Fay A. \& Arrighetti R. 1981. Esbozo Geológico de Cerro Partido. Inventario minero. Montevideo: Instituto Geológico del Uruguay.

Fernandes L.A.D., Tommasi A., Porcher C. 1992. Deformation patterns in the Southern Brazilian Branch of the Dom Feliciano Belt: A reappraisal. Journal of South American Earth Sciences, 5(1):77-96. https://doi. org/10.1016/0895-9811(92)90061-3

Ferrando L. \& Fernández A. 1971. Esquema tectónico cronoestratigráfico del Predevoniano en Uruguay. In: Congreso Brasilero de Geologia, 25. Atas... v. 1, p. 199-210.

Ford I. \& Gancio F. 1988. Asociación caolinita-montmorillonita en un paleosuelo del Terciario inferior del Uruguay (Fm. Asencio). Montevideo: Facultad de Agronomía, v. 12.
Fragoso-Cesar A.R.S. 1980. O Cráton do rio de La Plata e o Cinturão Dom Feliciano no Escudo Uruguaio - Sul-Riograndense. In: Congreso Brasileiro de Geologia, 31., Camboriú. Atas... v. 5, p. 2879-2892.

Fragoso-Cesar A.R.S., Fambrini G.L., Paes de Almeida R., Pelosi A.P.M.R., Janikian L., Riccomini C., Machado R., Nogueira A.C.R., Saes G.S. 2000. The Camaquã extensional basin: Neoproterozoic to early Cambrian sequences in southernmost Brazil. Revista Brasileira de Geociências, 30(3):442-445.

Fragoso-Cesar A.R.S., Machado \& Gómez-Rifas C. 1987. Observações sobre o Cinturão Dom Feliciano no Escudo Uruguaio e Correlações Com o Escudo do Rio Grande do Sul. In: Simpósio Sul-Brasileiro de Geologia, 3. Atas...

Gaucher C. 2000. Sedimentology, paleontology, and stratigraphy of the Arroyo del Soldado Group (Vendian to Cambrian, Uruguay). PhD Thesis, Beringeria, Wurzburg, $122 \mathrm{p}$.

Gaucher C. \& Sprechmann P. 1999. Upper Vendian skeletal fauna of the Arroyo del Sodado Group, Uruguay. Beringeria, 23:55-91.

Gaucher C., Boggiani P., Sprechmann P., Sial A., Fairchild T. 2003. Integrated correlation of the Vendian to Cambrian Arroyo del Soldado and Corumbá Groups (Uruguay and Brazil): paleogeographic, paleoclimatic and paleobiologic implications. Precambrian Research, 120(3-4):241-278. https://doi.org/10.1016/S0301-9268(02)00140-7

Gaucher C., Finney S.C., Poiré D.G., Valencia V.A., Grove M., Blanco G., Pamoukaghlián K., Peral L.G. 2008. Detrital zircon ages of Neoproterozoic sedimentary successions in Uruguay and Argentina: insights into the geological evolution of the Río de la Plata Craton. Precambrian Research, 167(1):150-170. https://www.researchgate.net/deref/dx.doi. org\%2F10.1016\%2Fj.precamres.2008.07.006

Gaucher C., Sprechmann P.,SchipilovA. 1996.UpperandMiddleProterozoic fossiliferous sedimentary sequences of the Nico Pérez Terrane of Uruguay: Lithostratigraphic units, paleontology, depositional environments and correlations. Neue Jahrbuch für Geologie und Paläontologie Abhandlunger, 199(3):339-367. http://dx.doi.org/10.1127/njgpa/199/1996/339

Gómez Rifas C. \& Masquelin H. 1996. Petrología y geoquímica de las rocas volcánicas cretáceas del Uruguay. In: Congreso Geológico Argentino, 12., Congreso de Exploración de Hidrocarburos, 3. Atas... p. 635-652.

Goñi J. 1958. Consideraciones sobre la estratigrafía del Proterozoico y Eopaleozoico uruguayos. Boletín de la Sociedad Brasileira de Geología, 7(1):91-97.

Goñi J. \& Hoffstetter K. 1964. Uruguay. Lexique stratigraphique international. v. 5, fasc. 9. Paris: CNRS.

González, P.D., Poiré D.G., Canalicchio J.M., García Repetto F. 2004. Geología y marco tectono-magmático de un enjambre longitudinal de diques del terreno Lavalleja (Minas, Uruguay). In: Congreso Uruguayo de Geología, 4. Atas... CD.

Goscombe B. \& Gray D. 2008. Structure and strain variation at mid-crustal levels in a trasnpresional orogeny: a review of Kaoko Belt structure and the character of West Gondwana amalgamation. Gondwana Research, 13(1):4585. https://doi.org/10.1016/j.gr.2007.07.002

Gross A.O.M.S., Droop G.T.R., Porcher C.C., Fernandes L.A.D. 2009. Petrology and thermobarometry of mafic granulites and migmatites from the Chafalote Metamorphic Suite: New insights into the Neoproterozoic P-T evolution of the Uruguayan-Sul-Rio-Grandense shield. Precambrian Research, 170(3-4):157-174. https://doi.org/10.1016/j. precamres.2009.01.011

Grotzinger J.P., Watters W.A., Knoll A.H. 2000. Calcified metazoans in thrombolite - stromatolite reefs of the terminal Proterozoic Nama Group, Namibia. Paleobiology, 26(3):334-359. https://doi. org/10.1666/0094-8373(2000)026\%3C0334:CMITSR\%3E2.0.CO;2

Hallsworth C.R. \& Knox R. 1999. Classification of sediments and sedimentary rocks. BGS Rock Classification Scheme, 3:1-46.

Hartmann L.A., Campal N., Santos J.O.S., McNaughton N.J., Bossi J., Schipilov A., Lafon J.M. 2001. Archean crust in the Rio de la Plata Craton, Uruguay - SHRIMP U-Pb zircon reconnaissance geochronology. Journal of South American Earth Sciences, 14(6):557-570. http://dx.doi. org/10.1016/S0895-9811(01)00055-4

Hartmann L.A., Santos J.O.S., Bossi J., Campal N., Schipilov A., McNaughton N.J. 2002. Zircon and titanite U-Pb geochronology of Neoproterozoic felsic magmatism on the eastern border of the Rio de la Plata Craton, Uruguay. Journal of South American Earth Sciences, 15(2):229-236. http://dx.doi. org/10.1016/S0895-9811(02)00030-5 
Hasui J., Carneiro C., Coimbra A. 1975. The Ribeira Folded belt. Revista Brasileira de Geociências, 5(4):257-266.

Janikian L., De Almeida R.P., Trindade D., Fragoso-Cesar A.R.S., D’Agrella-Filho M.S. Dantas E.L., Tohver E. 2008. The continental record of Ediacaran volcano-sedimentary successions in southern Brazil and their global implications. Terra Nova, 20(4):259-266. http://dx.doi. org/10.1111/j.1365-3121.2008.00814.x

Jones G.H. 1956. Memoria explicativa y mapa geológico de la región oriental del Departamento de Canelones. Boletín del Instituto Geológico del Uruguay, 34:1-193.

Kindle E.M. 1917. Some factors affecting the development of mud-cracks. The Journal of Geology, 25(2):135-144.

Konopásek J.K., Kosler J., Tajcmanova L., Ulrich S., Kitt S.L. 2008. Neoproterozoic igneous complex emplaced along major tectonic boundary in the Kaoko Belt (NW Nambia): ion probe and JA- ICP-MS dating of magmatic and metamorphic zircons. Journal of the Geological Society, 165(1):153-165. https://doi. org/10.1144/0016-76492006-192

Konopásek J.K., Kröner S., Kitt S.L., Passchier C.W., Kröner A. 2005. Oblique collision and evolution of large-scale transcurrent shear zones in the Kaoko Belt, NW Namibia. Precambrian Research, 136(2):139-157. http://dx.doi.org/10.1016/j.precamres.2004.10.005

Lamar D.L. 1992. Whittier-Elsinore fault system, Southern California. Special Publication - Association of Engineering Geologists, 4:255-267.

MacMillan J.G. 1933. Terrenos Precámbricos del Uruguay: carta geológica escala 1/50.000. Boletín del Instituto Geológico y de Perforaciones, 18:1-61.

Mallmann G., Chemale Jr. F., Ávila J.N., Kawashita K., Armstrong R.A. 2007. Isotope geochemistry and geochronology of the Nico Perez Terrane, Río de la Plata Craton, Uruguay. Gondwana Research, 12(4):489-508. https://doi. org/10.1016/j.gr.2007.01.002

Masquelin H. 1990. Análisis estructural de las zonas de cizalla en las migmatitas de Punta del Este-Uruguay. Actas Geologica Leopoldensia, 12:139-158

Masquelin H. \& Sánchez-Bettucci L. 1993. Propuesta de evolución tectonosedimentaria para la Cuenca de Piriápolis, Uruguay. Revista Brasileira de Geociências, 23(3):313-322.

Masquelin H., Fernandes L.A.D., Lenz C., Porcher C., McNaughton N. 2011. The Cerro Olivo Complex: a pre-collisional Neoproterozoic Magmatic Arc in Eastern Uruguay. International Geology Review, 54(10):1161-1183. https://doi.org/10.1080/00206814.2011.626597

Masquelin H., Silva Lara H., Sánchez Bettucci L., Núñez Demarco P., Pascual S., Muzio R., Peel E., Scaglia F. 2017. Lithologies, structure and basement-cover relationships in the schist belt of the Dom Feliciano Belt in Uruguay. Brazilian Journal of Geology, 47(1):21-42. http://dx.doi. org/10.1590/2317-4889201720160119

Miall A.D. 2006. The Geology of Fluvial Deposits, Sedimentary Facies, Basin Analysis, and Petroleum Geology. New York: Springer.

Midot D. 1984. Étude Géologique et diagnostic Métallogenique pour l'exploration du Secteur de Minas (Uruguay). PhD thesis, Paris, Université Pierre et Marie Curie, $175 \mathrm{p}$.

Munsell Color. 2009. Geological Rock Color Chart. Grand Rapids (MI): Munsell Color, $9 \mathrm{p}$.

Muzio R. 2000. Evolução petrológica e geocronologia do Maciço Alcalino Valle Chico, Uruguai. PhD thesis, Universidad Estadual Paulista, Rio Claro, $171 \mathrm{p}$.

Muzio R., Morales E., Veroslavsky G., Conti B., 2009. The Arequita Formation (Lower Cretaceous): petrographic features of the volcanic facies in the Laguna Merín Basin, East Uruguay. Latin-America Journal of Sedimentology and Basin Analysis, 16(1):19-28.

Núñez Demarco P. 2014. Caracterización geológica de la porción sur de la Formación barriga Negra y las relaciones con su basamento. $\mathrm{PhD}$ thesis, Universidad de la República, Uruguay, 171 p.

Oriolo S., Oyhantçabal P., Basei M.A.S., Wemmer K., Siegesmund S. 2016 The Nico Pérez Terrane (Uruguay): from Archean, crustal growth and connections with the Congo craton to late Neoproterozoic accretion to the Rio de la Plata craton. Precambrian Research, 280:147-160. http://dx.doi. org/10.1016/j.precamres.2016.04.014
Oyhantçabal P., Siegesmund S., Wemmer K. 2010. The Rio de la Plata Craton: a review of units, boundaries, ages and isotopic signature. International Journal of Earth Sciences, 100(2-3):201-220. https://doi. org/10.1007/s00531-010-0580-8

Oyhantçabal P., Siegesmund S., Wemmer K., Passchier C.W. 2011. The transpressional connection between Dom Feliciano and Kaoko belts at 580-550 Ma. International Journal of Earth Sciences, 100(2-3):379-390. https://doi.org/10.1007/s00531-010-0577-3

Oyhantçabal P., Siegesmund S., Wemmer K., Presnyakov S., Layer P. 2009 Geochronological constraints on the evolution of the southern Dom Feliciano Belt (Uruguay). Journal of the Geological Society, 166(6):10751084. https://doi.org/10.1144/0016-76492008-122

Pazos P.J., Sánchez-Bettucci L., Tofalo O.R. 2003. The record of the Varanger glaciation at the Río de la Plata craton, Vendian-Cambrian of Uruguay. Gondwana Research, 6(1):65-77.https://doi.org/10.1016/S1342-937X(05)70644-4

Pazos P.J., Bettucci L.S., Loureiro J. 2008. The Neoproterozoic glacial record in the Río de la Plata Craton: a critical reappraisal. Geological Society, London, Special Publications, 294(1):343-364. https://doi.org/10.1144/SP294.18

Pecoits E., Aubet N.R., Heaman L.M., Philippot P., Rosière C.A., Veroslavsky G., Konhauser K.O. 2016. U Pb detrital zircon ages from some Neoproterozoic successions of Uruguay: Provenance, stratigraphy and tectonic evolution. Journal of South American Earth Sciences, 71:108-130. http://dx.doi.org/10.1016/j.jsames.2016.07.003

Pettijohn F.J. 1949. Rocas Sedimentarias. 2a. ed. Buenos Aires, Eudeba Manuales.

Pickford M.H.L. 1995. Review of the Riphean, Vendian and early Cambrian palaeontology of the Otavi and Nama Groups, Namibia. Communications of the Geological Survey of Namibia, 10:57-81.

Plummer P.S. \& Gostin V.A. 1981. Shrinkage cracks: desiccation or synaeresis? Journal of Sedimentary Research, 51(4):1147-1156. https://doi. org/10.1306/212F7E4B-2B24-11D7-8648000102C1865D

Poiré D.G., González P.D., Canalicchio J.M., García Repetto F., Canessa N.D. 2005. Estratigrafía del Grupo Mina Verdún, Proterozoico de Minas, Uruguay. Latin American Journal of Sedimentology and Basin Analysis, 12(2):125-143.

Preciozzi F. 1989. Características petrográficas y metamórficas de la secuencia volcano-sedimentaria del Grupo Lavalleja (ciclo brasiliano) región Minas-Pan de Azúcar, Uruguay. Contribuciones a la Geología del Uruguay. Montevideo, Dirección Nacional de Minería y Geología.

Preciozzi F. \& Fay A. 1988. Memoria explicativa y mapa del fotoplano Pirarajá (F-23). Montevideo: Dirección Nacional de Minería y Geología, Facultad de Agronomía, Facultad de Humanidades y Ciencias, $15 \mathrm{p}$

Preciozzi F., Masquelin H., Sánchez L. 1993. Guía de Excursiones - Primer Simposio Internacional del Neoproterozoico Cámbrico de la Cuenca del Plata. La Paloma, Sociedad Uruguaya de Geologia.

Preciozzi F., Pena S., Arrighetti R. 1981. Síntesis geológica de la región Pan de Azúcar - Polanco. Montevideo, Dirección Nacional de Minería y Geología (DINAMIGE).

Preciozzi F., Spoturno J., Heinzen J. 1979. Carta Geo-Estructural de Uruguay escala 1:2.000.000. Montevideo, Ministerio de Industria y Energía, DINAMIGE, $57 \mathrm{p}$.

Preciozzi F., Spoturno J., Heinzen W., Rossi P. 1985. Carta Geológica de Uruguay a escala 1:500.000. Montevideo, Ministerio de Industria y Energía, DINAMIGE, $97 \mathrm{p}$

Pupin J.P. 1980. Zircon and granite petrology. Contributions to Mineralogy and Petrology, 73(3):207-220. https://doi.org/10.1007/BF00381441

Ramírez P.C. 1998. Provenance studies of the Paleogene Silverado Formation, San Joaquin Hills, Peninsular Ranges. In: Geological Society of America. Abstracts with Programs ... 30:60-61.

Rapalini A.E. \& Bettucci L.S. 2008. Widespread remagnetization of late Proterozoic sedimentary units of Uruguay and the apparent polar wander path for the Rio de La Plata craton. Geophysical Journal International, 174(1):55-74. https://doi.org/10.1111/j.1365-246X.2008.03771.x

Rapalini A.E., Tohver E., Bettucci L.S., Lossada A.C., Barcelona H., Pérez C. 2015. The late Neoproterozoic Sierra de las Ánimas Magmatic Complex and Playa Hermosa Formation, southern Uruguay, revisited: Paleogeographic implications of new paleomagnetic and precise geochronologic data. Precambrian Research, 259:143-155. http://dx.doi. org/10.1016/j.precamres.2014.11.021 
Rossello E., de Santa Ana H., Veroslavsky G. 1999. The Santa Lucia - Aigua - Merin lineament (Uruguay) is it an avorted mesozoic transtensional rifting during the Atlantic breakup? In: Rohn R. (Ed.). Bulletin. Brazil, UNESP, p. 712 .

Saalmann K., Gerdes A., Lahaye Y., Hartmann L.A., Remus M.V.D., Läufer A. 2011. Multiple accretions at the eastern margin of the Rio de la Plata craton: the pro-longed Brasiliano orogeny in southernmost Brazil. International Journal of Earth Sciences, 100(2):355-378. http://dx.doi. org/10.1007/s00531-010-0564-8

Salvador A. (Ed.). 1994. International stratigraphic guide: a guide to stratigraphic classification, terminology, and procedure. America, Geological Society of America, no. 30.

Sánchez Bettucci L. 1998. Evolución tectónica del Cinturón Dom Feliciano en la región Minas-Piriápolis, República Oriental del Uruguay. Thesis Doctoral, Facultad de Ciencias Exactas y Naturales, Universidad de Buenos Aires, Buenos Aires.

Sánchez Bettucci L. \& Loureiro J. 1999. Mapa geológico orientado a la prospección de rocas calcáreas en las hojas Arroyo del Soldado - Minas, Departamento de Lavalleja, escala 1:50.000. Uruguay, ANCAP.

Sánchez Bettucci L. \& Pazos P. 1996. Análisis paleoambiental y marco tectónico en la Cuenca Playa Verde, Piriápolis, Uruguay. In: Congreso Geológico Argentino, 13., Congreso de Exploración de Hidrocarburos I, 3. Actas... p. 405-412.

Sánchez Bettucci L. \& Ramos V.A. 1999. Aspectos geológicos de las rocas metavolcánicas y metasedimentarias del Grupo Lavalleja, sudeste de Uruguay. Brazilian Journal of Geology, 29(4):557-570.

Sánchez Bettucci L. \& Ramos V.A. 2002. Grupo Lavalleja: algunas reflexiones y precisiones. Revista Brasileira de Geociências, 32(4):602.

Sánchez Bettucci L., Cosarinsky M., Ramos V. 2001. Tectonic setting of the Late Proterozoic Lavalleja Group (Dom Feliciano Belt). Gondwana Research, 4(3):395-407. https://doi.org/10.1016/S1342-937X(05)70339-7

Sánchez Bettucci L., Loureiro J., Pascale A., Faraone M., Guerrero S. 2016. Relevamiento geofísico aeroportado de la porción sur del Uruguay. In: Congreso Uruguayo de Geología, 8., Montevideo, Uruguay. Actas...
Sánchez Bettucci L., Masquelin E., Peel E., Oyhantçabal P., Muzio R., Ledesma J.J., Preciozzi F. 2010a. Comment on "Provenance of the Arroyo del Soldado Group (Ediacaran to Cambrian, Uruguay): Implications for the paleogeographic evolution of southwestern Gondwana" [Precambrian Res. 171 (2009) 57-73]. Precambrian Research, 180:328-333. https://doi. org/10.1016/j.precamres.2009.11.011

Sánchez Bettucci L., Oyhantçabal P., Page S., Ramos V.A. 2003. Petrography and geochemistry of the Carapé Complex (Southeastern Uruguay). Gondwana Research, 6(1):89-105. https://doi.org/10.1016/ S1342-937X(05)70646-8

Sánchez Bettucci L., Peel E., Masquelin E. 2010b. Neoproterozoic tectonic synthesis of Uruguay. International Geology Review, 52(1):51-78. https:// www.tandfonline.com/author/Peel\%2C+Elena

Tófalo O.R. \& Morrás H.J. 2009. Evidencias paleoclimáticas en duricostras, paleosuelos y sedimentitas silicoclásticas del Cenozoico de Uruguay. Revista de la Asociación Geológica Argentina, 65 (4):674-686.

Umpierre M. \& Halpern M. 1971. Edades Sr - Rb del Sur de la República Oriental del Uruguay. Revista de la Asociación Geológica Argentina, 26:133-155.

Walther K. 1919. Líneas fundamentales de la Estructura Geológica de la República Oriental del Uruguay. Revista del Instituto Nacional de Agronomía, 3:3-67.

Walther K. 1927. Consideraciones sobre los restos de un elemento estructural, aún desconocido del Uruguay y el Brasil más meridional. Instituto de Geología y Perforaciones. Boletín, 10:1-381.

Weiss C.S. 1830. Über das südliche Ende des Gebirgszuges von Brasilien in der Provinz S. Pedro do Sul und der Banda oriental oder dem Staate von Montevideo; nach den Sammlungen des Herrn Fr. Sellow. Abhandlungen der Königlichen Akademie der Wissenschaften zu Berlin, 13:217-293.

Zhuravlev A.Y., Liñán E., Gámez Vintaned J.A., Debrenne F., Fedorov A.B. 2012. New finds of skeletal fossils in the terminal Neoproterozoic of the Siberian Platform and Spain. Acta Paleontologica Polonica, 57(1):205-224. http://dx.doi.org/10.4202/app.2010.0074 